\title{
Echoes of a flood pulse: short-term effects of record flooding of the Illinois River on floodplain lakes under ecological restoration
}

\author{
Michael J. Lemke · Heath M. Hagy • Keenan Dungey • Andrew F. Casper • \\ A. Maria Lemke $\cdot$ T. D. VanMiddlesworth $\cdot$ Angela Kent
}

Received: 24 September 2016/Revised: 3 April 2017/ Accepted: 22 April 2017/Published online: 29 May 2017

(C) The Author(s) 2017. This article is an open access publication

\begin{abstract}
The flood pulse drives primary productivity, biotic communities, and abiotic processes in large river systems; however, the effects of floods on restored floodplain lakes and associated wetlands are poorly understood. Record flooding of the Illinois River, Illinois, in 2013 reconnected two floodplain preserves under restoration that had been disconnected from the river by levees for $>80$ years. Differences in hydrological connections between sites created a natural experiment where field-based data collection
\end{abstract}

Electronic supplementary material The online version of this article (doi:10.1007/s10750-017-3220-5) contains supplementary material, which is available to authorized users.

Guest editors: Michael J. Lemke, A. Maria Lemke \& Jeffery W. Walk / Large-Scale Floodplain Restoration in the Illinois River Valley

\section{J. Lemke ( $ه)$}

Department of Biology, University of Illinois Springfield, One University Plaza, Springfield, IL 62703, USA

e-mail: mlemk1@uis.edu

\section{H. M. Hagy}

Illinois Natural History Survey, Forbes Biological Station - Bellrose Waterfowl Research Center, Prairie Research Institute at the University of Illinois at UrbanaChampaign, 20003 CR 1770E, Havana, IL 62644, USA e-mail: hhagy@illinois.edu

\section{K. Dungey}

Department of Chemistry, University of Illinois Springfield, One University Plaza, Springfield, IL 62703, USA could be employed to document flood effects. Levee failure and subsequent river connection at Merwin Preserve increased nutrient capture and floodwater retention, shifted microbial and invertebrate communities, increased fish species richness, spawning and nursery habitat, and stimulated production of moistsoil plant communities during summer drawdown that provided foraging habitat for spring-migrating waterfowl. However, increased hydrologic connectivity during the growing season resulted in loss of submersed vegetation and habitat for autumn-migrating waterfowl. In contrast, river water overtopped the levee at Emiquon Preserve during a 6-day event that resulted in marginal changes in the bacterial community and negligible changes in water quality and community diversity. Tradeoffs among ecological services should be carefully considered when

A. F. Casper - T. D. VanMiddlesworth

Illinois Natural History Survey, Illinois River Biological Station, Prairie Research Institute at the University of Illinois at Urbana-Champaign, 704 N. Schrader, Havana, IL 62644, USA

A. M. Lemke

The Nature Conservancy, Illinois River Project Office, 11304 North Prairie Road, Lewistown, IL 61542, USA

A. Kent

University of Illinois at Urbana-Champaign, Natural Resources and Environmental Sciences, 5 N-215 Turner Hall, 1102 S. Goodwin, Urbana, IL 61801, USA

e-mail: akent@illinois.edu 
reconnection of highly altered rivers to restored lakes and wetlands is proposed.

Keywords Flood $\cdot$ River $\cdot$ Floodplain $\cdot$ Restoration ecology

\section{Introduction}

A defining characteristic in the ecology of floodplain-river systems is the nature of the lateral water connection, especially the way riverine floods pulse into floodplain wetlands and lakes during the spring. These flood pulses increase species richness, diversity, and overall productivity (Bayley, 1995; Sparks, 1995; Galat et al., 1998; Robertson et al., 2001). Junk et al. (1989) introduced the flood pulse concept that states that the "principle driving force for the existence, productivity, and interactions of major biota in river-floodplain systems is the flood pulse." Subsequently, many studies have examined the basic underpinning that floodplain-river connections are important drivers of biodiversity and have suggested that other factors also contribute to the ecology of large river systems in temperate areas (Tockner et al., 2000; Junk \& Wantzen, 2004). However, frequent and high-magnitude floods during the growing season can be associated with many undesirable effects (Jackson \& Pringle, 2010), such as high-nutrient loadings (Kreiling et al., 2013), decreased invertebrate diversity (Galir \& Palijan, 2012; Górski et al., 2013), dispersal of invasive species, suppressed growth of submersed aquatic vegetation, and limited recruitment of woody vegetation (Sparks, 1995; Robertson et al., 2001; Tockner \& Stanford, 2002). Responses of abiotic and biotic factors to different flooding intensities need to be better understood in order to quantify tradeoffs among ecological services associated with benefits of restoring and reconnecting backwater lakes and wetlands, particularly in hydrologically modified river systems (Ward et al., 2001; Tockner \& Stanford, 2002). Increased understanding of the responses of the floodplain environment to inundation can be especially important when trying to ascertain the restoration capacity of highly altered river systems.

Drainage and levee districts are designed to disconnect floodplains from the river for the benefit of agricultural production and urban development, and subsequently disrupt the natural seasonality of annual river flood pulses, restricting nutrient exchanges and impeding reproductive efforts of plants, fishes, and wildlife that are adapted to floodplains (Simons et al., 2001; Boucek \& Rehage, 2015). Such districts are land aggregations within former river floodplains that have been isolated by levees and are managed with drainage infrastructure to promote row-crop agriculture and other human development purposes. Former floodplain lakes and wetlands within drainage and levee districts represent habitat for fish and wildlife that are protected from potentially damaging floods (Bajer et al., 2009; Hagy et al., 2016; Hine et al., 2016; VanMiddlesworth et al., 2016). Catastrophic flooding associated with levee failure or with trending patterns of increased frequency and magnitude of riverine floods can expose these restored areas to levels of inundation that exceed historical conditions (Bellrose et al., 1983; Sparks, 1995; Criss \& Shock, 2001; Pinter et al., 2006). Thus, restoration through extensive reconnection of floodplain habitats in highly modified rivers appears to be ill-advised (Sparks et al., 2016) and restoration goals should be directed towards attributes associated with extant conditions rather than historical norms (Jackson \& Pringle, 2010; Kreiling et al., 2013).

Large-river restoration activities can create open, partial, or limited connections between riverine and floodplain habitats (Garvey et al., 2007; O'Hara et al., 2008; Lemke et al., 2017a). Floodplains with open or partial river connections provide breeding habitats for fish, increase sediment deposition and nutrient processing in floodplain lakes and wetlands, and reduce downstream flood potential via attenuation (Opperman et al., 2010). However, these benefits are greatly influenced by multiple alterations to rivers that can result in frequent flood pulses of high magnitudes. Limited river-floodplain connections can help prevent unseasonably high and variable water levels during the growing season that might otherwise inhibit aquatic vegetation production (Moore et al., 2010; Stafford et al., 2010), increase immigration of undesirable species (e.g., Bajer et al., 2009), and allow the untimely transport of nutrients that can disrupt the food web infrastructure (Schiemer et al., 2006). Case studies that document the tradeoffs between riverfloodplain reconnections and restoration efforts are needed to better inform future conservation and 
Table 1 Predicted responses of environmental conditions and aquatic community structure to partial and limited flood conditions at the Merwin and Emiquon Preserves during record flooding along the Illinois River, Illinois, U.S. in spring of 2013

\begin{tabular}{|c|c|c|}
\hline Predictions & Partial connection: Merwin Preserve & Limited connection: Emiquon Preserve \\
\hline $\begin{array}{l}\text { Loadings from river } \\
\text { (e.g., nutrient, } \\
\text { sediment) }\end{array}$ & High & Low \\
\hline Transparency & Low (high turbidity) & Little change \\
\hline Dissolved oxygen & High at surface; low near sediments & Uniform throughout water column \\
\hline Bacteria community & Seasonal shift + shift with algae change & Minor and short-term shifts with season \\
\hline Algal community & High biomass & Low biomass \\
\hline $\begin{array}{l}\text { Zooplankton } \\
\text { community }\end{array}$ & $\begin{array}{l}\text { Dominated by small species typical of riverine communities } \\
\text { and low diversity }\end{array}$ & $\begin{array}{l}\text { Larger species typical of backwaters and } \\
\text { high diversity }\end{array}$ \\
\hline $\begin{array}{l}\text { Aquatic macrophyte } \\
\text { community }\end{array}$ & $\begin{array}{l}\text { Decreased aquatic bed and persistent, increased non- } \\
\text { persistent emergent vegetation }\end{array}$ & $\begin{array}{l}\text { Decreased persistent emergent, increased } \\
\text { aquatic bed vegetation }\end{array}$ \\
\hline Fish community & $\begin{array}{l}\text { Increased species diversity primarily from riverine species; } \\
\text { increased growth or productivity }\end{array}$ & $\begin{array}{l}\text { Little change in species diversity, increased } \\
\text { growth or productivity }\end{array}$ \\
\hline $\begin{array}{l}\text { Waterfowl and } \\
\text { Waterbirds }\end{array}$ & $\begin{array}{l}\text { Dominance shifted from herbivorous and granivorous to } \\
\text { piscivorous birds }\end{array}$ & Little change; increase in herbivorous birds \\
\hline
\end{tabular}

In this study, a partial connection is defined as a levee breach that created a two-way exchange during moderate river water levels (Merwin) and a limited connection as a short-term one-way flow of water from the river into the preserve over an intact levee during the flood event (Emiquon). Long-term data were available from both sites for aquatic macrophytes, fishes, waterfowl, and waterbirds

management decisions (Sparks et al., 1998; Palmer et al., 2005).

During the spring of 2013, record flood waters in the Illinois River overtopped levees at two preserves (Merwin and Emiquon) that were under restoration and reconnected these former floodplains with the river for the first time in more than 80 years. Deconstruction of drainage infrastructure that had sustained agricultural production from the 1920s through 1999 (Merwin Preserve) and 2006 (Emiquon Preserve) allowed precipitation accumulation to create a complex of wetlands, shallow lakes, and associated aquatic-terrestrial plant communities (Hine et al., 2016; Sparks et al., 2016). Both preserves received flood waters during the spring of 2013; however, the extent, duration, and magnitude of the river-floodplain connection differed between the two sites (Lemke et al., 2014). A levee breach at the Merwin Preserve created a two-way hydrologic connection between the restored floodplain area and the river that allowed water exchanges at moderately high river stages (i.e., partial connection). In contrast, river water flowed into the Emiquon Preserve for six days over approximately $500 \mathrm{~m}$ of levee and through culverts connected to an adjacently flooded drainage and levee district, resulting in a brief inflow of water rather than the establishment of a two-way connection (i.e., limited connection).

The objective of this investigation was to document the effects of partial and limited river-floodplain connectivity on water chemistry and biotic assemblages in two restored floodplain lake-wetland complexes. We compared the post-flood response of biotic communities to available pre-flood data for waterbirds, aquatic vegetation, fishes, invertebrates, and bacteria. Because river channels generally have distinctly different water chemistry and biotic assemblages than isolated floodplain lakes and wetlands (Amoros \& Bornette, 2002; Dembkowski \& Miranda, 2011), we predicted that environmental conditions and aquatic community structure would vary with the magnitude and duration of river connectivity (Table 1). More specifically, we predicted that longterm inundation of flood waters into the Merwin Preserve would result in a backwater ecosystem that closely resembled riverine conditions. Increased nutrient loadings would result in high algal biomass initially; however, high suspended sediment loadings would reduce light penetration that would subsequently lower algal production. It was thought that the bacterial species would change due to influx of riverine species and that the bacteria, overall, would 
change due to both seasonal and algal conditions. We predicted that high turbidity and frequent water level fluctuations during the growing season would be detrimental to submersed and emergent aquatic macrophytes (Bellrose et al., 1979) and that these effects would be reflected by reduced abundances of waterfowl and other waterbirds, with a shift in dominance from herbivorous and granivorous waterbirds to piscivorous species (Bajer et al., 2009). We predicted a backwater zooplankton community that closely resembled that of the river primarily composed of small species and that the open connectivity between the preserve and the river would provide increased movement of riverine fishes such that the fish diversity would increase.

We forecasted that short-term flooding at the Emiquon Preserve would also result in an initial increase of nutrients that would be sufficient to briefly change bacterioplankton composition, yet would quickly be assimilated by algae and zooplankton. Given the low magnitude of the flooding relative to the large area of the site, we expected minimal algal and zooplankton response, and that the zooplankton community would exhibit higher biomass and diversity compared to that of the Merwin Preserve. Although riverine fishes would undoubtedly be introduced into the backwater site during the flood event, we did not expect measurable changes in fish communities at the Emiquon Preserve. Similarly, we expected no effects on waterbird or aquatic vegetation communities in response to the limited connection to the river.

\section{Methods}

Study area

Emiquon (Fulton County, IL) and Merwin (Brown County, IL) Preserves are located in the LaGrange and Alton Pools, respectively, of the Illinois River that flows through the state of Illinois southwest from Chicago, Illinois, to near St. Louis, Missouri, in the central United States (Fig. 1). Details on the history and land use transitions are given in Lemke et al. (2017a). Merwin Preserve is located on a former floodplain (484 ha) of the Illinois River that was isolated from the river by levees and farmed from the 1920s through 1998. Two floodplain lakes, Elbow and Long Lakes, occupied the current preserve area prior to its separation from the river. Restoration by The Nature Conservancy began in 1999, and by 2003 more than half of the former floodplain comprised highquality emergent marsh with abundant coverage of emergent, floating-leaf, and submersed aquatic vegetation that is largely absent from other areas of the Illinois River Valley (IRV; Blodgett et al., 2007; Stafford et al., 2010).

Emiquon Preserve is owned and managed by The Nature Conservancy and is a former floodplain (2,723 ha) of the Illinois River that was isolated from the river behind drainage and levee district levees in the early 1920s for agricultural purposes (Havera et al., 2003). Two historical floodplain lakes at the Emiquon Preserve, Thompson and Flag lakes, were among the largest along the La Grange Reach of the river and among the most important to waterbirds within the entire Illinois River prior to isolation and drainage (Havera et al., 2003). Levee district pumps were disabled in 2007 and more than 1,800 ha of aquatic vegetation communities and deep water areas existed within the historical lake basins by autumn 2009 (Hine et al., 2016). Aquatic vegetation recolonized from natural sources and included floatingleaved, submersed, and emergent aquatic vegetation communities (Hine et al., 2016). More than 30 native fish species were stocked during the first year of restoration at the Emiquon Preserve (VanMiddlesworth et al., 2014; Sparks et al., 2016) and the preserve typically hosts more than $30 \%$ of the waterbird use days in the region (Hagy et al., 2016). In contrast, an initial carp-dominated fish community at the Merwin Preserve naturally transitioned to one composed of 14 species dominated by largemouth bass (Micropterus salmoides Lacepède, 1802) and bluegill (Lepomis macrochirus Rafinesque, 1819) within a few years of restoration (Heske \& Herkert, 2007; Pegg et al., 2007; Solomon et al., 2014). Native prairie and forest species were established at both preserves with extensive seeding and planting. Limited planting of aquatic vegetation occurred and most aquatic species appeared to germinate from the seed bank or through recolonization (Hine et al., 2016).

Water quality

In situ measurements included water temperature, dissolved oxygen, $\mathrm{pH}$, conductivity (YSI Pro Plus, Yellow Springs, OH), turbidity (Hach Turbidimeter 


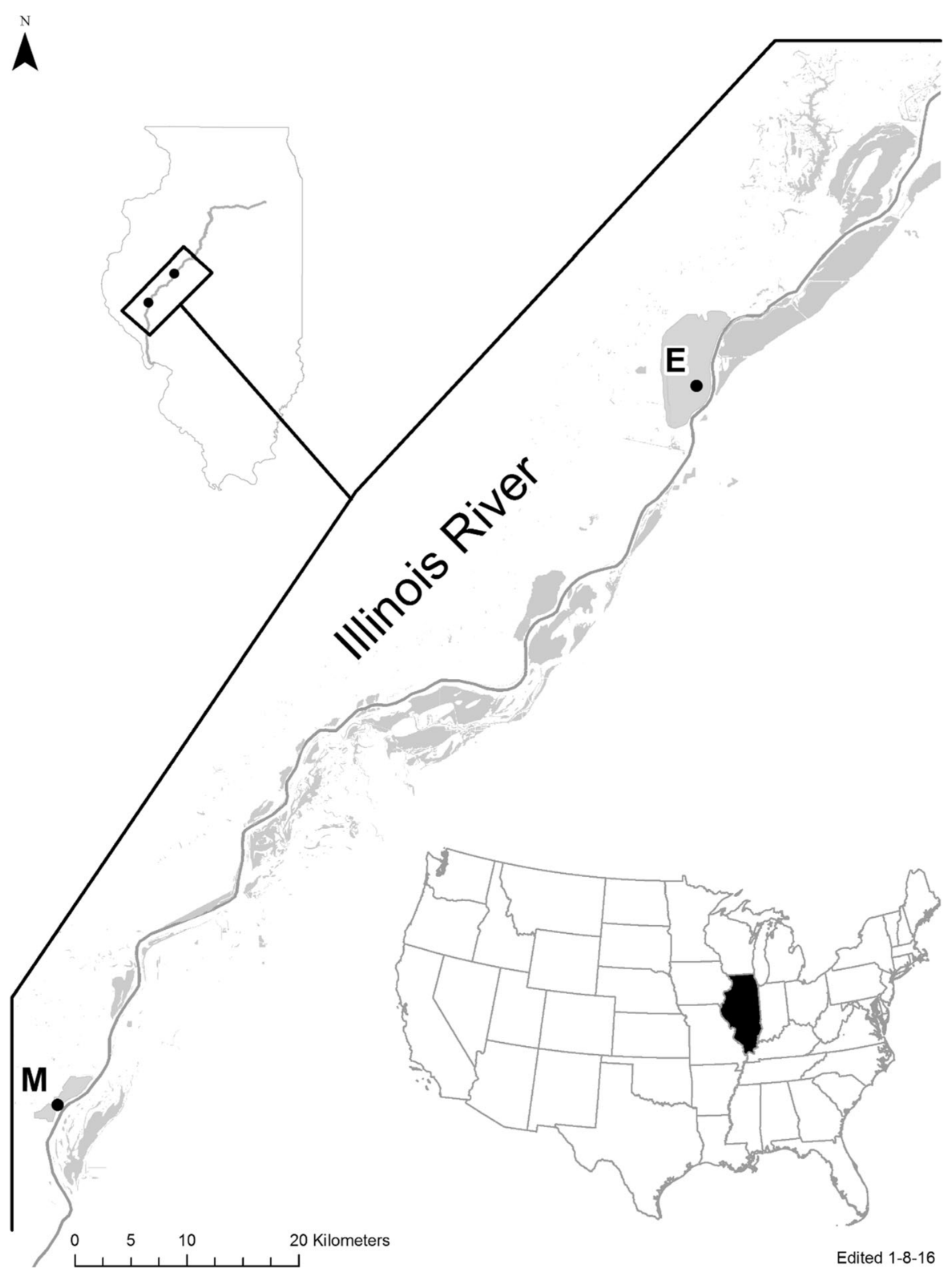

Fig. 1 Locations of Long Lake at the Merwin Preserve $(M)$ and Thompson Lake at the Emiquon Preserve $(E)$ within the LaGrange Reach of the Illinois River, Illinois, that were sampled during this study

2100, Loveland, CO), total depth, and Secchi depth at bi-weekly (Merwin: June 2013-March 2014, Emiquon: Dec. 2013- March 2014) or weekly intervals (Emiquon: March 2013-Nov. 2013). Water samples (Merwin: $n=4$, Emiquon: $n=3$ ) for total suspended solids (TSS) and chlorophyll $a(\mathrm{chl} a)$ were collected $10 \mathrm{~cm}$ under the water surface and stored on ice until returned to the laboratory. Aliquots were filtered through two separate Whatman GF/F glass fiber filters (approx. $0.6 \mu \mathrm{m}$ pores; GE Healthcare Bio-Sciences, Pittsburgh, PA) and stored at $-20^{\circ} \mathrm{C}$ until analyzed for TSS (APHA, 1998, method 2540E) and chl $a$. The chl $a$ method (Wetzel \& Likens, 2000) was modified with an overnight acetone extraction step completed in the dark at $20^{\circ} \mathrm{C}$ and subsequently analyzed using a Cary 100Bio UV-Visible spectrophotometer (Agilent Tech. Santa Clara, CA). Other water analyses included nitrate and soluble reactive phosphorus (Dionex ICS- 
2100 ion chromatography, AS-17 column, AS-DV auto-sampler, Sunnyvale, CA), total ammonia (Hach salicylate method with HACH DR/580 colorimeter), total phosphorus, and total nitrogen (APHA, 1998, methods 4500-P D and 4500-N B on a Lachat QuikChem system by Hach). Surface sediments were collected from open water and near shore sites in June, July, and August of 2013 and potential denitrification rates were determined using the acetylene block method with a Shimadzu GC-ECD (Tiedje, 1982).

\section{Community composition}

\section{Bacteria}

Pelagic bacterial community composition was completed using Automated Ribosomal Intergenic Spacer Analysis (ARISA). Lake water samples (about $100 \mathrm{ml}$; collected bi-weekly, and location noted above) were filtered $(0.2 \mu \mathrm{m})$ and DNA was extracted from the filter (Millipore Isopore, Billerica, MA) using FastDNA Spin kits (MP Biomedicals, Solon, OH). Polymerase chain reactions (PCR conditions; $94^{\circ} \mathrm{C}$ two min., and 30 cycles of $94^{\circ} \mathrm{C}$ for $35 \mathrm{~s}, 55^{\circ} \mathrm{C}$ for $45 \mathrm{~s}, 72^{\circ} \mathrm{C}$ for $2 \mathrm{~min}$; final extension $72^{\circ} \mathrm{C}$ for two min.) were performed on $1 \mu \mathrm{l}$ of diluted DNA to amplify the 23S-16S intergenic spacer regions of domain Bacteria assemblages using primers 1406f, 5'-TGYACACACCGCCCGT-3' (labeled with a 5' phosphoramidite dye 6FAM) and 23Sr, $5^{\prime}$-GGG TTBCCCCATTCRG-3' primers. Lengths of amplified intergenic products were analyzed on an ABI PRISM 3730xl DNA Analyzer Applied Biosystems (Foster City CA, USA), and GeneMarker (SoftGenetics version 1.75) was used for alignment, size-calling, and analysis following conditions described in Paver et al. (2013).

\section{Zooplankton}

Zooplankton were sampled using a 1.7-m-long PVC tube (10-cm dia.) fitted with a stop-valve near the bottom. Tube samplers collect integrated samples throughout the water column that provide zooplankton densities comparable to other sampling devices (Lewis \& Saunders, 1979; DeVries \& Stein, 1991), and have commonly been used to sample shallow lake and wetland habitats (e.g., Parkos et al., 2003; Lemke \& Benke, 2009; Schuyler et al., 2009; Burdis \&
Hoxmeier, 2011). This sampling approach was used consistently during this study to quantify zooplankton in these shallow, vegetated floodplain lakes in order that samples could be compared between sites and within each site over time.

Eight samples were collected each month from June 2013 through April 2014 within Long Lake (Merwin Preserve) from randomized sites along a transect in the center of the lake $(n=4)$, and shallower sites along the shoreline $(n=4)$. No flooded emergent aquatic vegetation existed during sampling periods. Sample volumes varied with river inundation and subsequent depth of the floodplain lake. Multiple samples were integrated into a single sample when water levels were low at sampling sites, such that on most dates $(89 \%$ of all samples) sample volumes exceeded 6.51 (range $=6.5-18.51$, minimum volume $=41$ ). On several occasions when the river inundated the site in June 2013 and March 2014, water depths were greater than the tube sampler length resulting in 14 of the 96 total samples collected in which the sampler did not reach the bottom, but instead sampled the top $32-76 \%$ of the water column. Twelve samples were collected monthly from May 2013 through April 2014 within Thompson Lake (Emiquon Preserve) from randomized sites along a transect in the center of the lake $(n=4)$, shallower sites along the shoreline $(n=4)$, and emergent vegetation habitats $(n=4)$. Sample volumes varied with water depth at each site. Multiple samples were integrated into a single sample when water levels were low at sampling sites, such that on most dates $(96 \%$ of all samples) sample volumes exceeded 6.51 (range $=6.5-17.51$, minimum volume $=41$ ). Open water sites were consistently deeper than the length of the tube sampler such that top $60 \%$ of the water column was sampled at these sites.

All samples were concentrated on a $20-\mu \mathrm{m}$ mesh sieve, preserved in 4\% sucrose-formalin (Haney \& Hall, 1973; Prepas, 1978) with Rose Bengal, and subsequently stored in $70 \%$ ethanol. All samples were analyzed from Merwin Preserve. Due to time constraints related to processing time, six samples were randomly selected from each sampling date from Emiquon Preserve ( $n=2$ per habitat) for analysis. Samples were analyzed using the Utermohl sedimentation technique with a minimum count of 200 organisms (Lund et al., 1958; Beaver et al., 2014). Counts were conducted at $\times 100$ magnification and densities were estimated as numbers $1^{-1}$ based on the 
volumes of water that were sampled. To obtain count estimates, subsamples of each water column sample were stirred using a magnetic stirrer and calibrated aliquots were counted. If the total tally was less than 200 after three replicate aliquots were counted, additional aliquots up to the entire sample were examined. Taxonomic identification followed Ruttner-Kolisko (1974), Edmundson (1959), and Pennak (1989). Current nomenclature was verified with electronic databases such as the Integrated Taxonomic Information System. Larger zooplankton species were quantified by scanning the entire sample. Dry mass ( $\mu \mathrm{g}$ DM) estimates were calculated using published length-mass relationships (McCauley, 1984) and

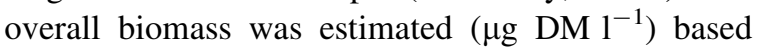
on the volume of water sampled. Ten specimens were measured for common species but as few as one for rare taxa. Cladocerans were measured from the tip of the head to the end of the body (shell spines excluded) and copepods were measured from the tip of the head to the insertion of the caudal ramus. Dry weight biomass calculations of rotifers were based on length and length/width relationships that provide volume estimates, which were converted to dry weight as described in McCauley (1984) using a ratio of 0.10 for dry weight: wet weight (Pace \& Orcutt, 1981). In accordance with McCauley (1984), a mean biomass was computed for the measured number of individuals for each sample location that was then multiplied times the species abundance to produce a species biomass for each sample.

\section{Aquatic vegetation}

Submersed aquatic vegetation (SAV) was sampled monthly at random sites during the 2013 post-flood growing season (Emiquon: May-September 2013; Merwin: July-September 2013). Densities for SAV were estimated as percent coverage using a vegetation rake method. Emergent, non-rooted floating-leaved, and rooted floating-leaved aquatic vegetation densities were estimated as percent cover within a 2-m perimeter (Yin et al., 2000). Six years of pre-flood data were available for the Emiquon Preserve; however, only anecdotal pre-flood data were available for the Merwin Preserve. Cover maps of all vegetation communities and other wetland-associated cover types were produced for 2007-2013 at Emiquon and Merwin Preserves using aerial photographs and heads up digitizing. Ground-truthing was used to assist aerial photo interpretation in all years at Emiquon Preserve and in 2013 at Merwin Preserve following procedures described by Hine et al. (2016). We used available aerial imagery (e.g., USDA National Agricultural Imaging Program) and ancillary observations, data, photographs, and experience of field personnel to classify cover types and digitize aerial photos during the autumn at Merwin Preserve for 2007-2012, as systematically collected ground-truthing data was not available for this site and time period.

\section{Fishes}

Fish assemblages were sampled each month from April to October (2013) at the Emiquon Preserve and July to October (2013) at the Merwin Preserve. Fish were collected during daylight using a pulsed-DC electrofishing boat with runs (15 min each) at random and fixed sites using methods described by Solomon et al. (2014) and VanMiddlesworth et al. (2016). Fixed locations at Merwin encompassed former drainage ditches. Sampling at Emiquon included randomly selected electrofishing sites and random sites stratified by an effective depth range (generally 1-3 m, unobstructed by dense vegetation).

\section{Waterbirds}

Waterfowl species and select species of other waterbirds (hereafter, waterbirds) were quantified at Emiquon and Merwin Preserves during autumn migration (October-January, 2008-2013) using aerial surveys as part of the Illinois Natural History Survey's (INHS) long-term aerial waterfowl inventory (Havera, 1999). Waterbirds were also identified and quantified at Emiquon Preserve during spring migration (FebruaryApril, 2008-2014) using ground surveys. Similar spring ground surveys were not conducted at Merwin Preserve; however, diving ducks (Aythyinae) were enumerated weekly during spring migration (MarchApril, 2012-2014) at Merwin Preserve as part of a concurrent aerial waterfowl study. Aerial surveys were conducted by an INHS biologist with $>10$ years of experience from a fixed-wing, single-engine aircraft at altitudes of $60-140 \mathrm{~m}$ and speeds of 160-240 $\mathrm{km} \mathrm{h}^{-1}$ (Havera, 1999). Waterbird use days were calculated by guild (i.e., dabbling ducks [Tribe Anatini], diving duck, granivores [primarily consume 
plant seeds and tubers], piscivores [primarily consume fish], insectivores [primarily consume invertebrates, including bivalves]) during each monitoring period (Havera, 1999).

\section{Simulating frequency of river-floodplain connectivity}

River gage data from the U.S. Army Corps of Engineers at the LaGrange Lock and Dam $(3.5 \mathrm{~km}$ north of Merwin Preserve) were used to simulate hydrologic conditions at the Merwin Preserve following the 2013 flood to examine the flood frequency that would have occurred if the river-floodplain breach had existed during the previous 25 years. Frequencies at which water would enter Merwin Preserve through the levee breach were simulated during key periods for fish, wildlife, and aquatic vegetation growth during 1980-2014. Similarly, we calculated the frequency of years over the same period during which water levels in the Illinois River would allow gravity flow of water into Emiquon through a water control structure during peak spring migration of waterbirds (February 15April 15; Havera, 1999). We used U.S. Army Corps of Engineers gage data from the Illinois River near Havana, IL, located approximately $2 \mathrm{~km}$ downstream of a proposed water control structure for the Emiquon Preserve, and assumed that at least $131.7 \mathrm{~m}(1 \mathrm{~m}$ above flat pool and the bottom sill of the proposed structure) would be needed for at least 21 days to inundate significant portions of the drawdown area in most years given mean river levels.

\section{Statistical analysis}

Water quality measurements represent averages \pm standard error of the mean. For bacterial community analysis, a Bray-Curtis similarity index was generated to create non-metric multidimensional scaling (MDS) plots to evaluate spatial and temporal patterns, and analysis of similarity (ANOSIM) used to determine differences between/among groups. ANOSIM generates the $\mathrm{R}$ test statistic (values between -1 and 1); a score of 1 indicates complete separation, 0 indicates no separation. MDS and ANOSIM were done in Primer (PRIMER-E, Lutton, Ivybridge, UK). Preflood vegetation data existed for the Emiquon Preserve only and was used to examine changes in the aquatic vegetation community post-flood. Abundances and biomass were calculated for each zooplankton species or taxon by sample date. Relative abundances were calculated by sample date and averaged across dates to estimate mean annual relative abundances and biomass for each major taxonomic group. Diversity was calculated for each sample date using the Shannon diversity index: $\mathrm{H}^{\prime}=-\Sigma p_{i} \log p_{i}$, where $p_{i}$ is the proportion of the total number of individuals occurring in species $i$. Fish species richness was calculated as the total number of species collected in any given year. General trends in waterbird duck use days were quantified over time and significant effects were noted if observations fell outside of $95 \%$ confidence intervals around the long-term averages for autumn (2007-2012) at Emiquon and Merwin, spring (2008-2013) at Emiquon, and spring at Merwin (2012 and 2013).

\section{Results}

Case study 1: Effects of flooding and partial connection at the Merwin Preserve

\section{Hydrology}

Water levels inside Merwin Preserve tracked river elevations during the initial flood event as river water entered the backwater site through the levee breach on April 25, 2013 (Fig. 2A). The height of the breach at $133 \mathrm{~m}$ above mean sea level (AMSL) did not allow water to recede back into the river until a second, deeper notch was constructed in the levee at $129 \mathrm{~m}$ AMSL in mid-June. As the river elevations fell below that of the notch, water levels receded until only historical agricultural ditches and small areas of lake basins were inundated that continued to decline from evaporation during the summer.

\section{Water quality}

No temperature or oxygen stratification occurred in the water column during the study (Fig. 2B, C) due to polymixis from wind fetch effects on a lake of this depth. Mixed Illinois River and Long Lake waters had a dissolved nitrate concentration of $1.18 \pm 0.07 \mathrm{mg} \mathrm{N} / \mathrm{l}$ on June 4, 2013 (initial flood-event sampling) (Fig. 2D); however, concentrations decreased by over a factor of 100 three months after the levee breach to $0.01 \pm 0.01 \mathrm{mg} \mathrm{N} / \mathrm{l}$. Soluble reactive phosphorus 
Fig. 2 Illinois River and Merwin Preserve water elevations (A), and mean $( \pm \mathrm{SE}, n=4)$ water temperature $(\mathbf{B})$, dissolved oxygen $(\mathbf{C})$, soluble reactive phosphorus (SRP) and nitrate-nitrogen $\left(\mathrm{NO}_{3}{ }^{-}-\mathrm{N}\right)$ concentrations $(\mathbf{D})$, and total suspended solids and chlorophyll $a$ concentrations (E) from April 2013 to April 2014

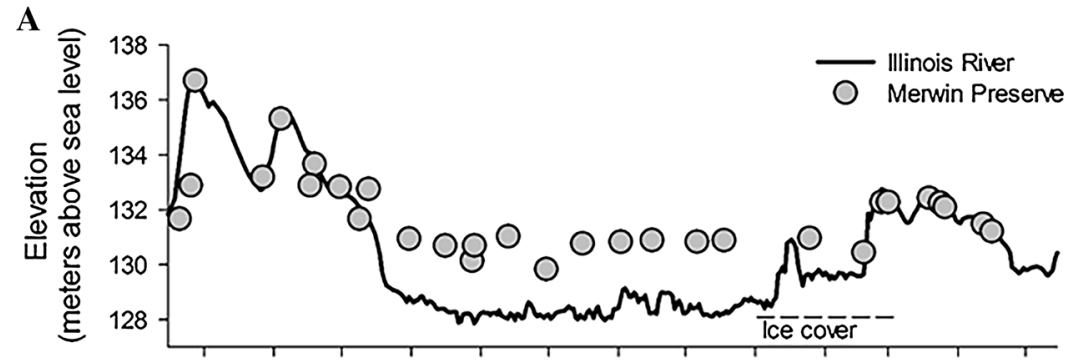

B

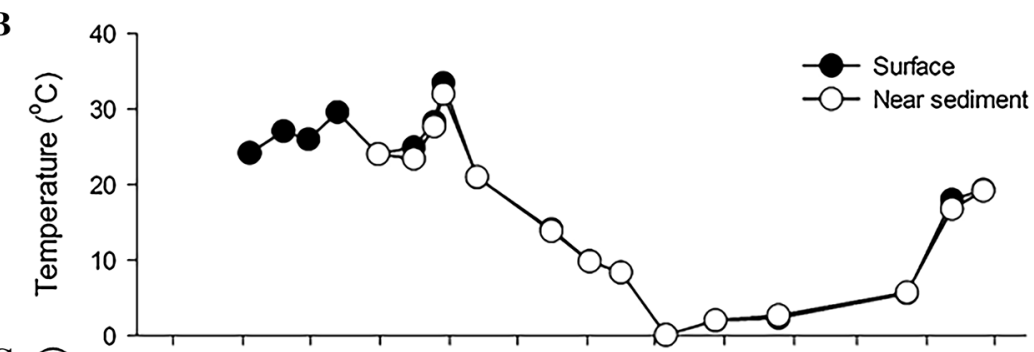

C
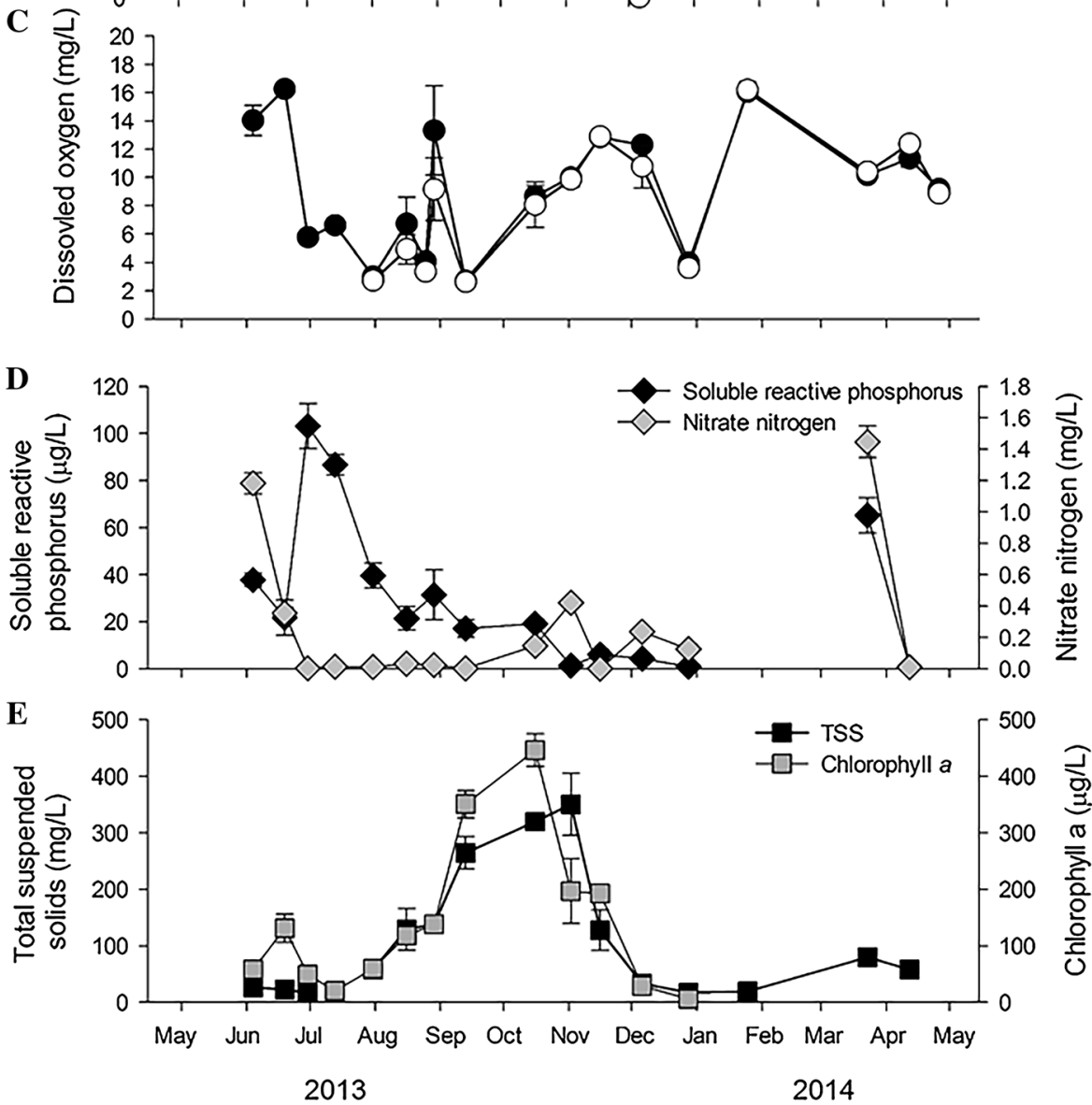

(SRP) increased nearly three-fold ( $38 \pm 3$ to $103 \pm 10 \mu \mathrm{g}$ P/l) during the second river pulse after June 6,2013 , followed by a rapid decline later in the summer. A mid-winter rise in the Illinois River and associated spring rains resulted in a series of flood pulses into Long Lake at Merwin Preserve and a subsequent surge of nitrate and SRP concentrations in the spring of 2014 (Fig. 2D). Turbidity (Table S1) and 

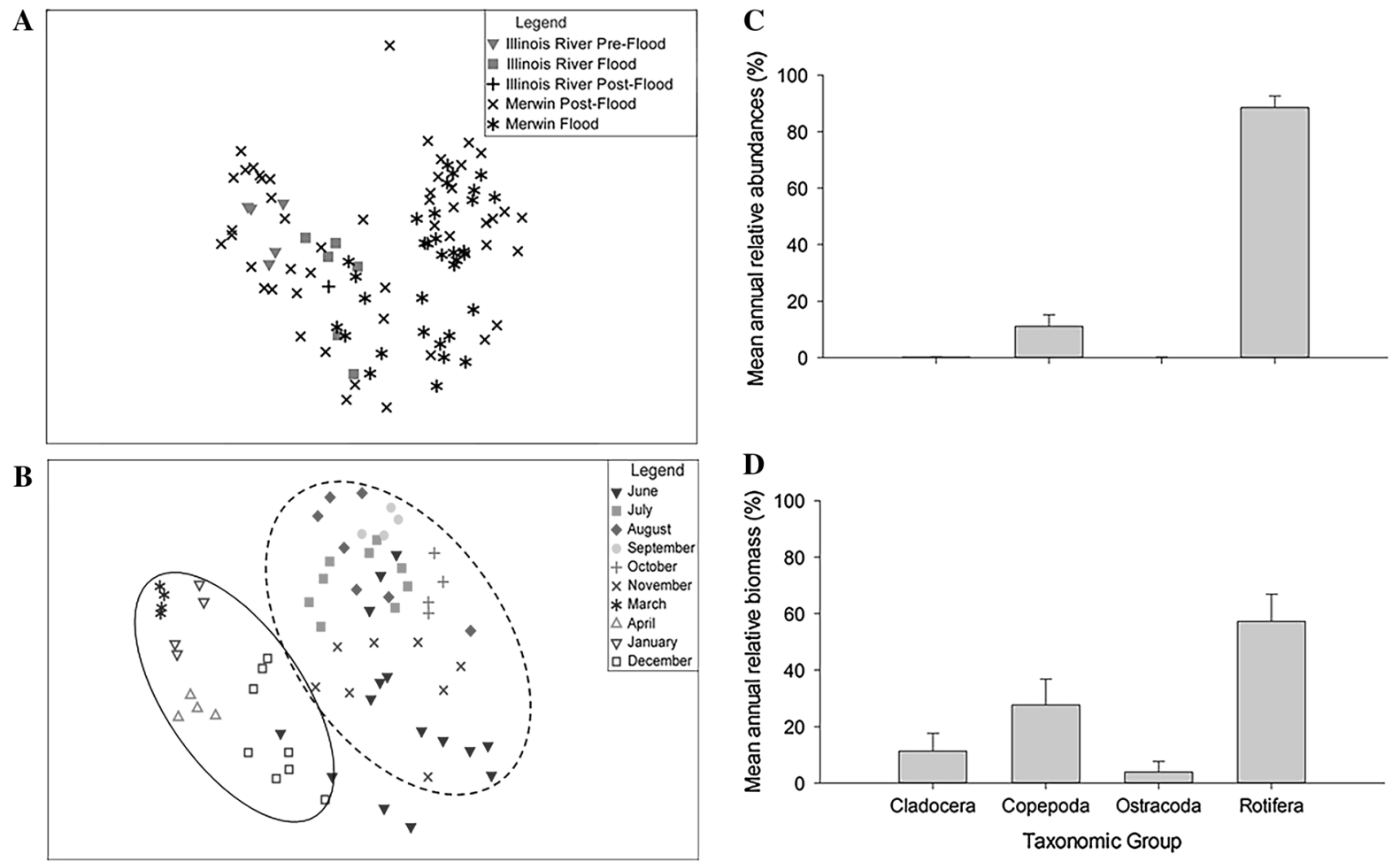

Fig. 3 Microfauna at Long Lake (Merwin Preserve) includes MDS plots of bacterioplankton composition (ARISA) from the Illinois River (pre-flood, flood, and post-flood) and from Long Lake (flood, post-flood) (A), bacterioplankton data coded by

month for Long Lake (solid circle, winter-spring; dashed circle, summer-autumn) (B), and relative abundances (C) and biomass (D) of major microcrustacean taxonomic groups

TSS (Fig. 2E) increased from $27 \pm 5$ to $399 \pm 34$ NTU and from $26 \pm 2$ to $350 \pm 55 \mathrm{mg} / \mathrm{l}$, respectively, in the autumn of 2013. These increases were due to sediment load from the river and an algal bloom (percentage of the particulates that were organic remained approximately constant during the study, $43 \pm 5 \%$; Table S1), as indicated by the increase in chl $a$ concentrations in the autumn of 2013 (Fig. 2E). July 2013 sediment cores had the largest denitrification rates of $36 \pm 3$ and $50 \pm 5 \mathrm{mg} \mathrm{NO}-\mathrm{N} / \mathrm{kg} / \mathrm{h}$, from open water and near shore sites, respectively (Table S1).

\section{Bacterioplankton}

Bacterioplankton composition differed among hydrological (i.e., flood vs. post-flood) and seasonal classifications (ANOSIM R $=0.695 ; P<0.001$ (Fig. 3A, B). Long Lake bacterioplankton composition resembled the Illinois River during the flood, then the communities diverged (Fig. 3A). The temporal pattern was clearer by month in the post-flood period (Fig. 3B). A general pattern of succession was seen

over time, with a distinction between winter-spring and summer-autumn composition (ANOSIM $R=0.692$; $P<0.001$ for comparisons among month).

\section{Zooplankton}

Rotifers comprised the majority of total abundances in Long Lake during 2013-2014, ranging from 56 to $100 \%$ on any given sample date (annual mean $=88.5 \%$, Fig. 3C). Relative biomass of rotifers ranged from 11 to $99 \%$ across sampling dates (annual mean $=57.2 \%$, Fig. 3D), dominated by Synchaeta spp., Brachionus caudatus (Barrois \& Daday, 1894), B. calyciflorus (Pallas, 1766), Rotaria spp., and Trichocerca rousseleti (Voigt, 1902). Relative abundances of copepods ranged from less than 1 to $28 \%$ across sampling dates, averaging $11.1 \%$ for the sampling year (Fig. 3C). Copepods comprised from $<1$ to $88 \%$ of total zooplankton biomass on any given sampling date, averaging $27.6 \%$ of the mean annual biomass (Fig. 3D), dominated by Eucyclops pectinifer (Cragin, 1883), cyclopoid copepodites, and nauplii. 
Cladocerans made up $<1 \%$ of total abundances on all sampling dates except for July 2013 (1.2\%), averaging $0.2 \%$ of total annual abundances (Fig. 3C). However, cladoceran relative biomass ranged from 0 to $67 \%$ across sampling dates (annual mean $=11.3 \%$, Fig. 3D), dominated by Diaphanosoma brachyurum (Liévin, 1848), Daphnia lumholtzi (Sars, 1885), and Chydorus sphaericus (O.F. Müller, 1776). Ostracods comprised $<1 \%$ of annual abundances and $3.9 \%$ of total annual biomass. Mean annual microcrustacean biomass for Long Lake was $15.5 \pm 7.8 \mu \mathrm{g}$ dry mass (DM) $1^{-1}$ and species diversity $\left(\mathrm{H}^{\prime}\right)$ was 1.06 . Cladoceran and copepod densities remained low throughout the sampling year (Fig. 4A) relative to rotifer densities (Fig. 4B). Similar abundance patterns were observed for copepods and rotifers showing initial high abundances during the 2013 flood, a decline in abundances during the summer and autumn, followed by several abundance peaks in early autumn (September-October), mid-winter (January-February), and again in early spring (April). Total abundance patterns (Fig. 4C) were highly influenced by rotifer densities and monthly biomass patterns reflected changes in total densities.

\section{Aquatic vegetation}

Increased drainage capacity of Merwin Preserve provided by the additional notch constructed in the river levee resulted in a nearly complete drawdown in latesummer 2013 that limited growth of persistent emergent $(-100 \%)$ and aquatic bed vegetation $(-100 \%)$ compared to their long-term averages (Fig. 5A). Nonpersistent emergent vegetation $(+13.0 \%)$ and open water habitats $(+24.5 \%)$ were higher than long-term averages in 2013. Submersed, emergent, and floatingleaved aquatic plant species were not detected at any of the random sites in inundated areas at the Merwin Preserve in 2013; however, American lotus (Nelumbo lutea [Willd.] Pers.) was anecdotally observed in 15 small beds within flooded areas of Merwin Preserve in July before complete drawdown and completion of the cover maps.

\section{Fishes}

Fish species richness exhibited an upward trend at the Merwin Preserve in 2014, although there was some variability over the years since sampling began in
1999 (Fig. 5B). Fish samples were dominated by smaller bodied fish common to backwater lakes in this region, including gizzard shad (Dorosoma cepedianum, Lesueur, 1818), bullhead species (Ameiurus spp.), Western mosquito fish (Gambusia affinis, Baird \& Girard, 1853), and juvenile buffalo species (Ictiobus spp.). Fish species richness during the flood year (2013) was greater than the long-term average for Merwin Preserve and was greater than nine of the previous 13 years (Fig. 5B). After the minor, low intensity flooding of 2013, size structure of one of the most common backwater fish species, the bluegill (Rafinesque, 1819) showed a broad range of sizes with the median length of $120 \mathrm{~mm}$ (Fig. 5C), corresponding to a 2- or 3-year-old age class in this system. In addition, a large cohort of fishes $<50 \mathrm{~mm}$ corresponded to juvenile fish produced in the year of the flood.

\section{Waterbirds}

Fewer bird use days occurred at the Merwin Preserve in autumn 2013 than the long-term average for dabbling ducks $(-88.9 \%)$, diving ducks $(-100 \%)$, and total waterbirds $(-35.6 \%)$ (Table 2). Similarly, use days were less than the long-term average for waterbirds classified as primarily granivores, herbivores, and invertivores $(-85.8 \%,-99.7 \%$, and $-39.9 \%$, respectively); however, piscivore use days were greater $(+157.4 \%)$ in 2013 than the long-term average. Diving duck use days during the spring of 2014 were much greater than in previous years $(9,700 \%)$, but low water in early spring 2012 and 2013 limited available habitat within Merwin Preserve and contributed partially to this dramatic increase (Table 2).

Case study 2: Effects of a limited river connection at the Emiquon Preserve

\section{Hydrology and water quality}

Emiquon Preserve received a limited flood pulse from the Illinois River as the levees were overtopped for 6 days in April 2013 (Fig. 6A). Temperature stratification was only evident during mid-summer (Fig. 6B) even though oxygen stratification was apparent in Thompson Lake from the time of flooding and persisted into the autumn (Fig. 6C). Flood waters 
Fig. 4 Mean ( \pm 1 SE) abundances of copepods and cladocerans $(\mathbf{A})$, rotifers (B), and total microcrustacean abundances and mean biomass $(\mathbf{C})$ collected monthly $(n=8)$ from Long Lake (Merwin Preserve) June 2013 through April 2014
$\mathbf{A}$

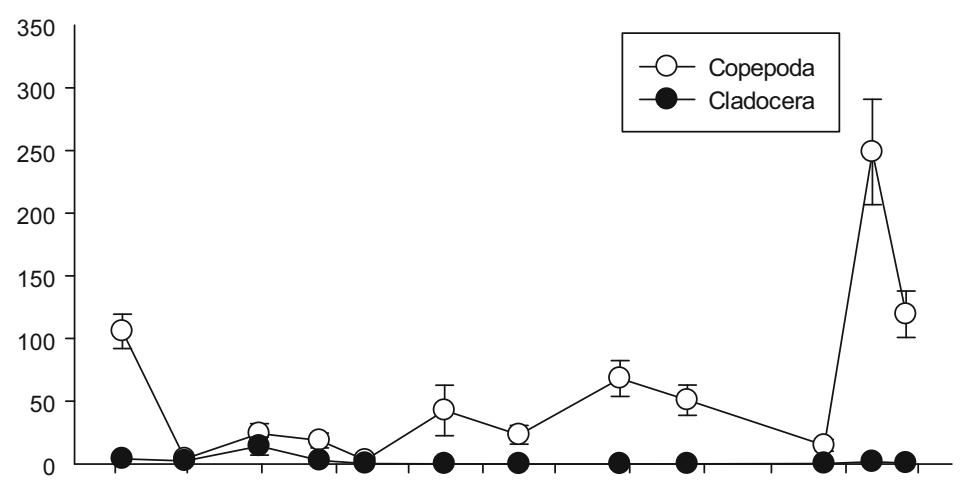

B

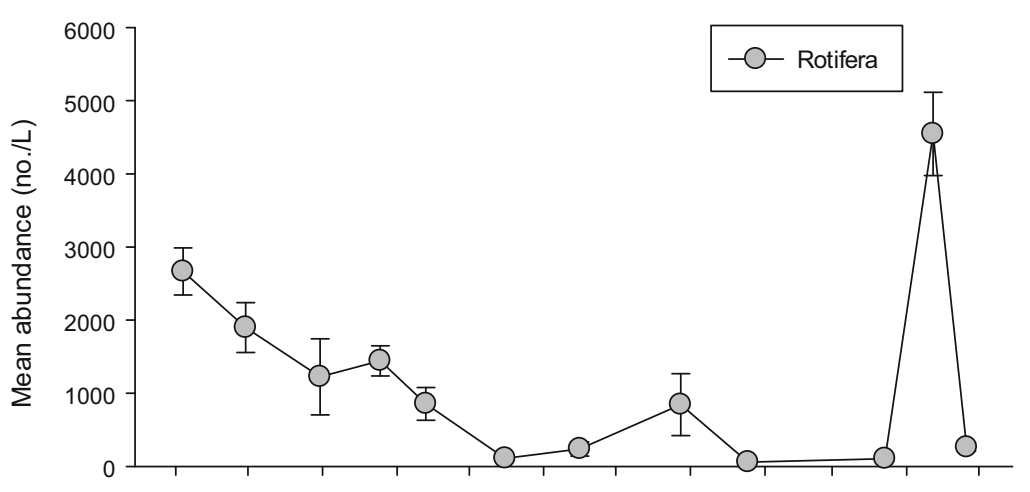

C

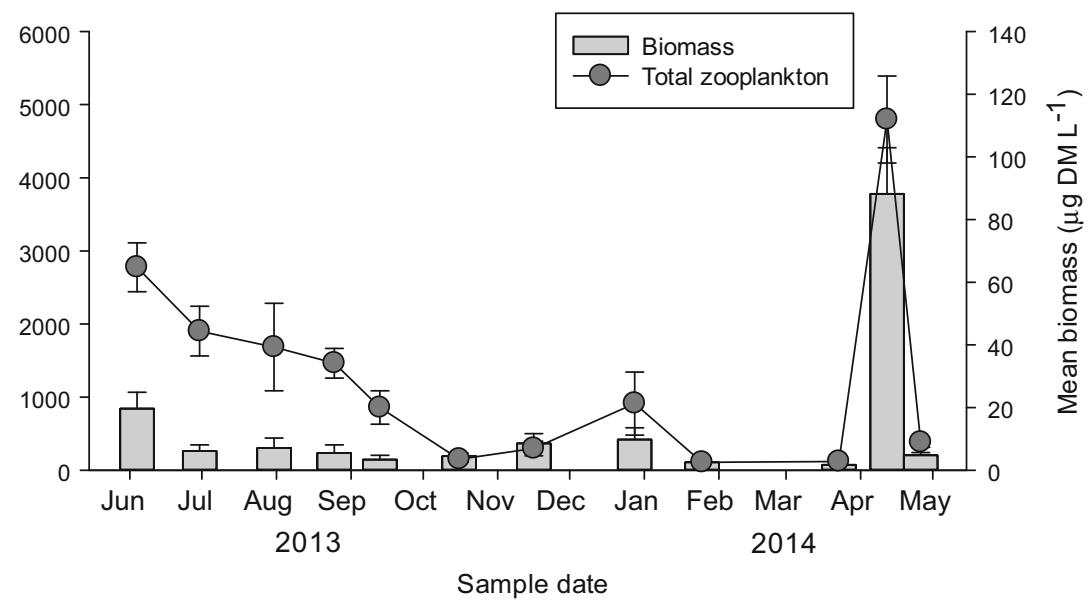

created a short-term increase in nitrate concentrations from $0.06 \pm 0.06$ to $1.01 \pm 0.84 \mathrm{mgN} / \mathrm{l}$ (Fig. 6D). A mid-summer increase occurred in SRP from $3.4 \pm 0.3$ to $86.2 \pm 8.6 \mu \mathrm{g} / \mathrm{l}$, opposite of patterns observed from 2009 to 2012 in which SRP decreased from a spring high of approximately $154 \mu \mathrm{gP} / \mathrm{l}$ (Lemke et al., 2017b). Subsequent to the SRP peak was an increase in chlorophyll $a$ concentrations and TSS in latesummer (Fig. 6E). Specific conductivity (Table S1) varied little after inundation $(347 \pm 3 \mu \mathrm{S} / \mathrm{cm})$ despite the input of higher conductivity river water $(706 \pm 27$ $\mu \mathrm{S} / \mathrm{cm})$. July 2013 sediment cores had the largest denitrification rates of $36 \pm 3$ and $50 \pm 6 \mathrm{mg} \mathrm{NO}_{3}-\mathrm{N} /$ $\mathrm{kg} / \mathrm{h}$, from open water and near shore sites, respectively (Table S1).

\section{Bacterioplankton}

Illinois River bacterioplankton composition was different than that of Thompson Lake (Fig. 7A). In the 


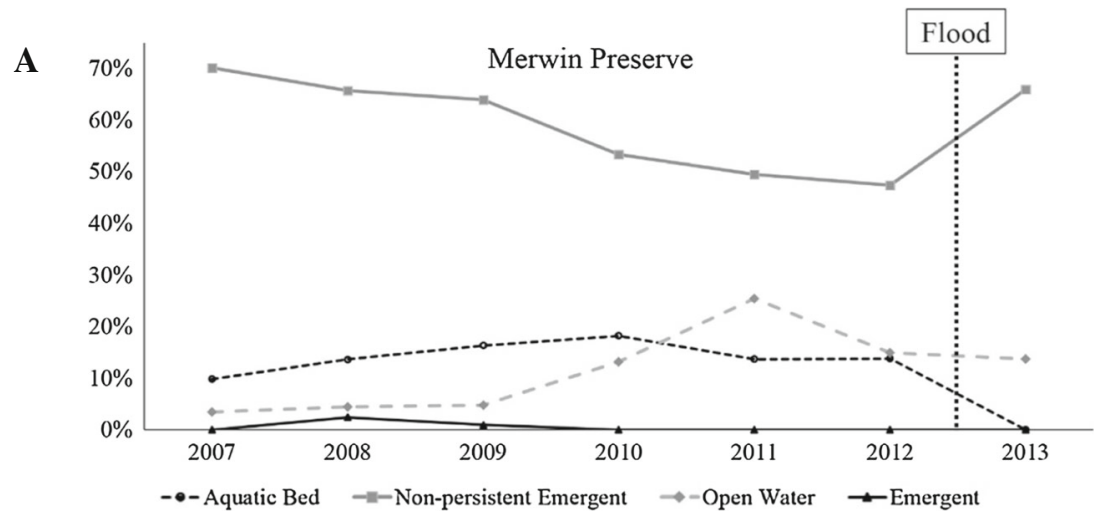

B
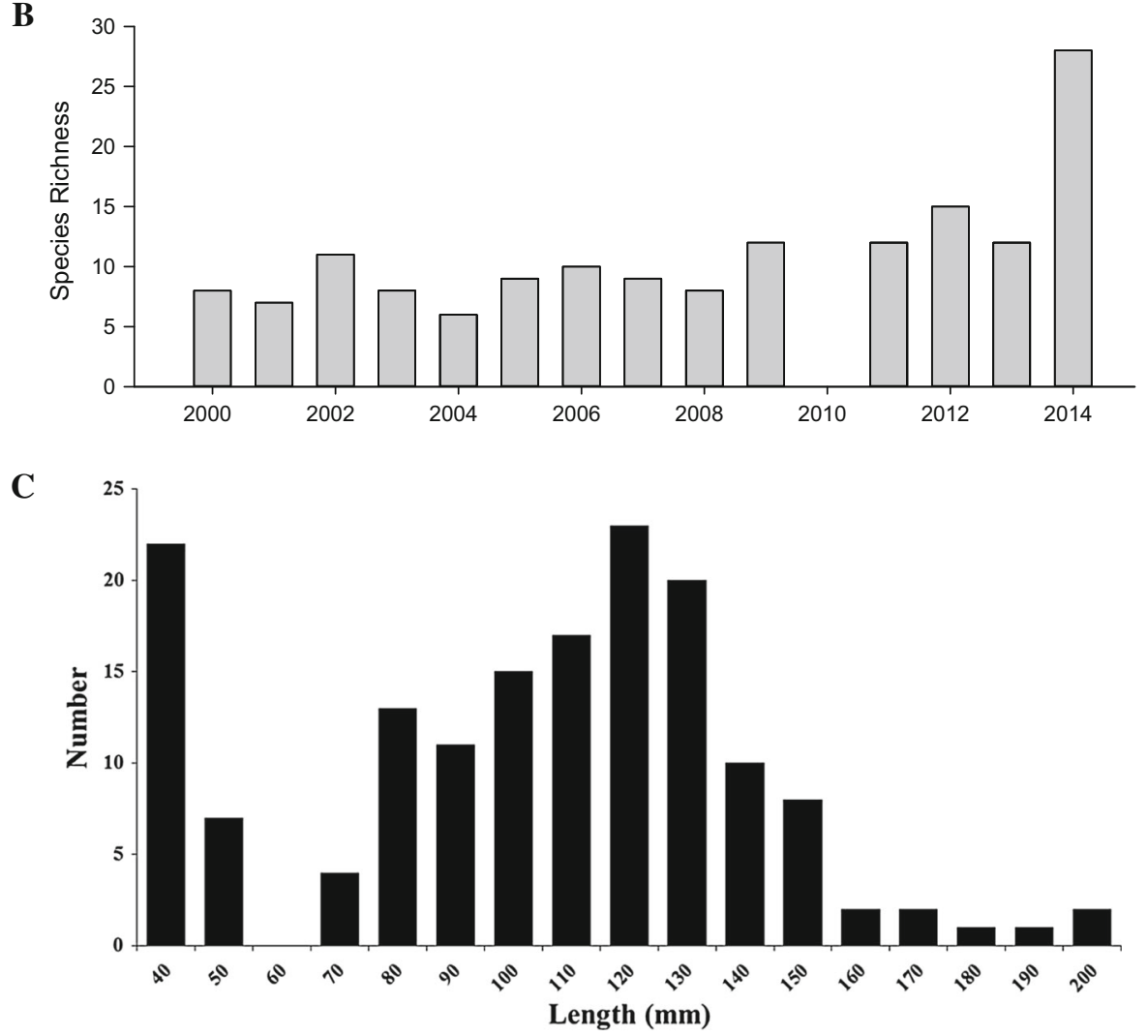

Fig. 5 Percent cover of aquatic vegetation types at Long Lake (Merwin Preserve) during autumn 2012 and 2013 (A), total fish species richness 1999-2014 (B) and bluegill (Lepomis

Emiquon Preserve, bacterioplankton species and abundances changed after the flood period probably due to the addition of Illinois River bacterioplankton, as opposed to a response to changing water quality. The communities became more similar during the flood recovery period (ANOSIM Global $R$ : 0.221; significance level of sample statistic: 0.001). As a macrochirus) population size structure (C) collected at the preserve July through October 2013

point of reference, 2013 spring (March-May) bacterial composition was compared to years prior to (2011, 2012) and after the 2013 flood (2014, Fig. 7B). Through 2012 (a drought year) and 2013, communities were similar and then in 2013, a slight difference was noted likely due to the flood event, then a slow recovery was noted in 2014, showing that 2014 


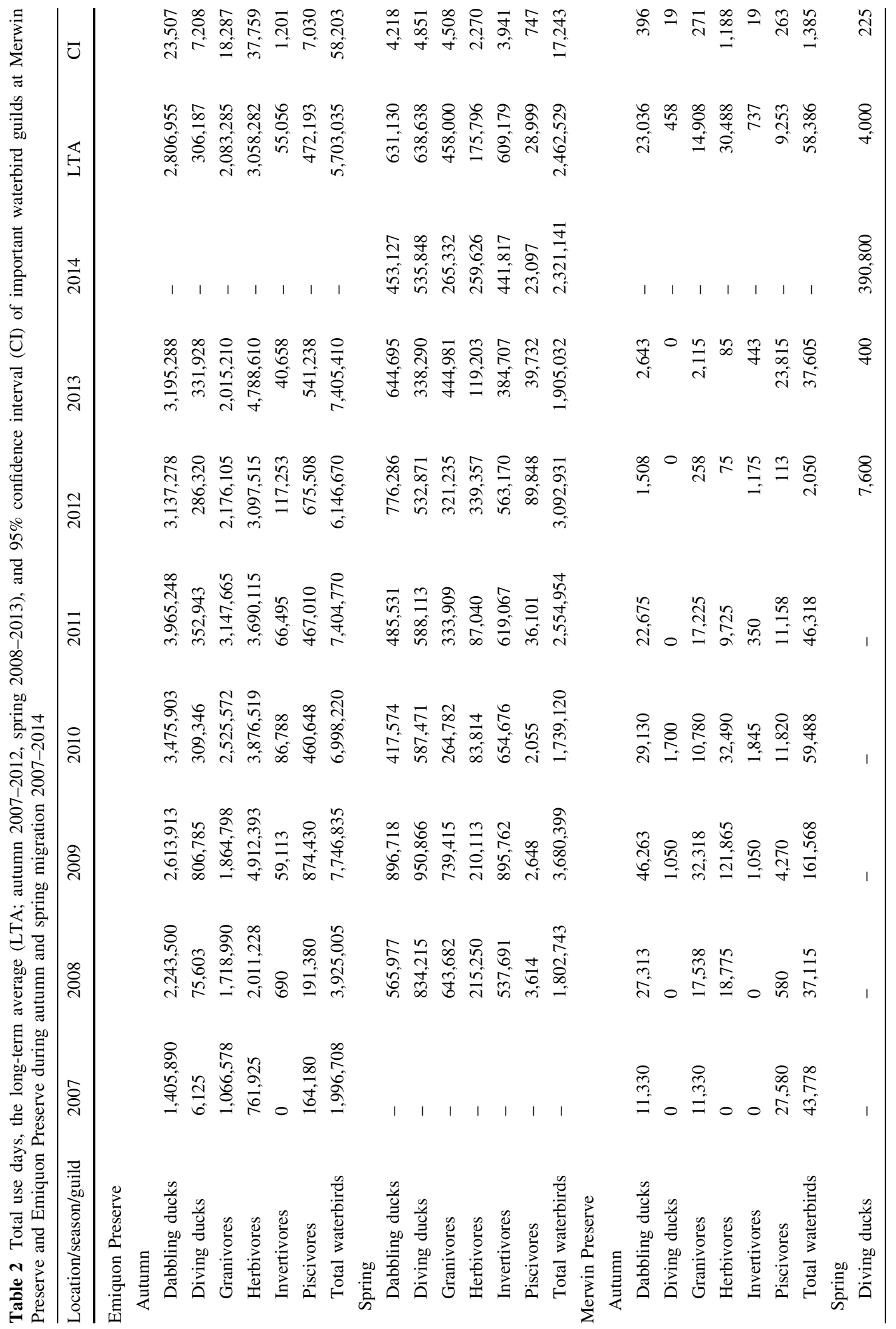


Fig. 6 Illinois River and Thompson Lake (Emiquon Preserve) water elevations (A), and mean ( \pm SE, $n=3)$ water temperature $(\mathbf{B})$, dissolved oxygen $(\mathbf{C})$, soluble reactive phosphorus (SRP) and nitrate-nitrogen $\left(\mathrm{NO}_{3}{ }^{-}-\mathrm{N}\right)$ concentrations (D), and total suspended solids and chlorophyll $a$ concentrations (E) from April 2013 to April 2014

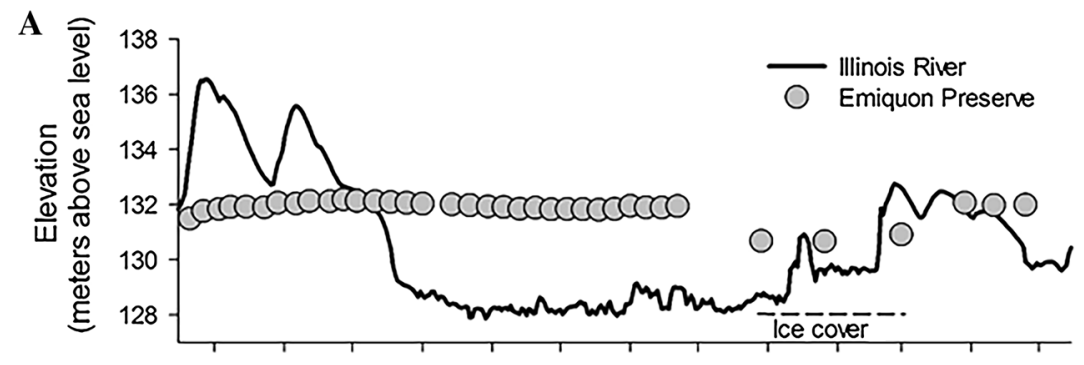

B

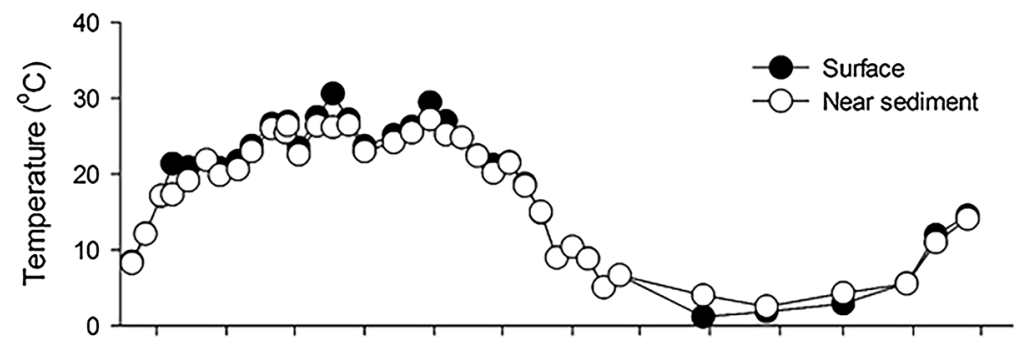

C
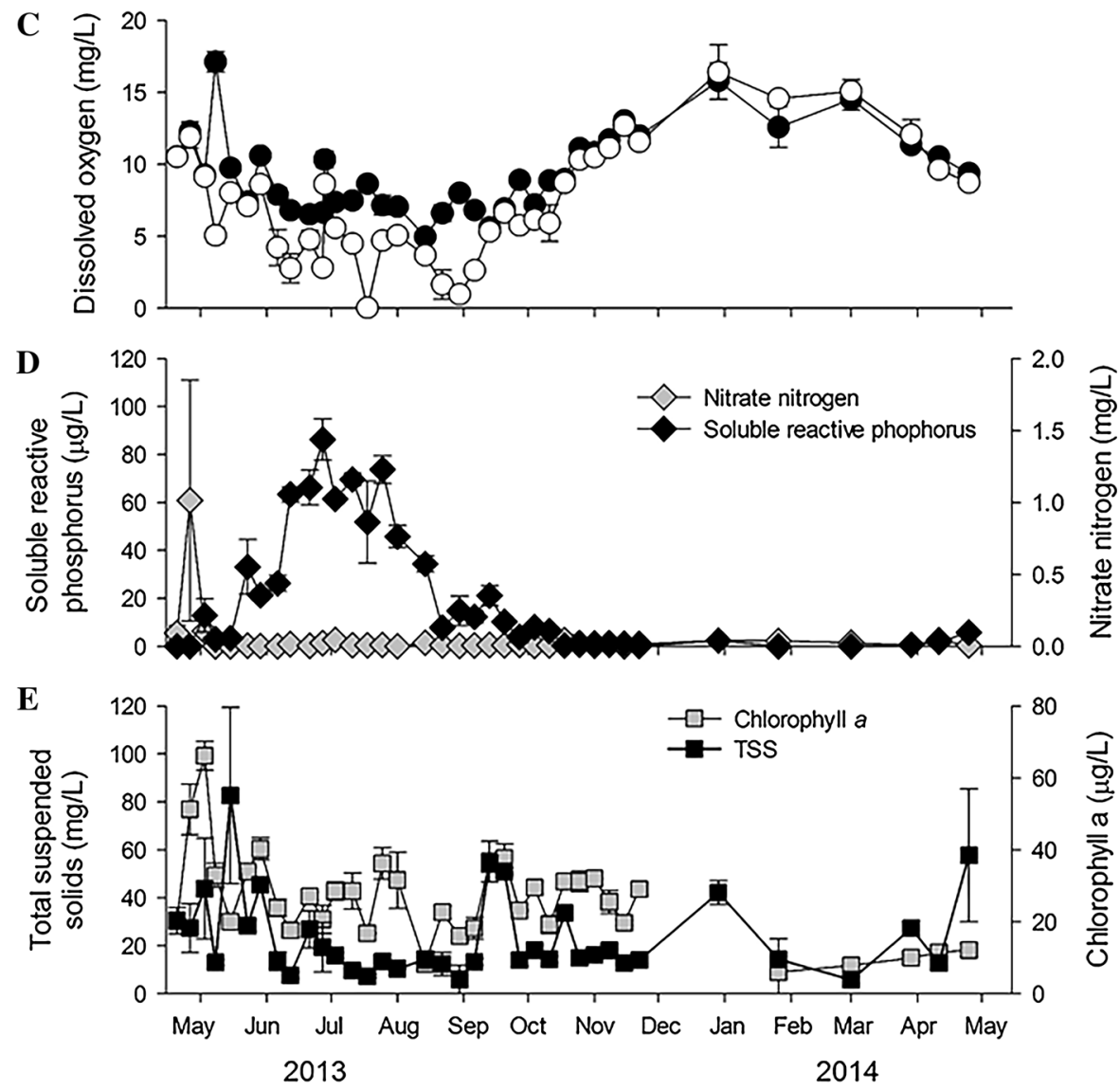

bacterial community composition was more similar to that of 2011 than 2013. The outlying group of points below the main group (Fig. 7B) occurred in early March 04-09, 2012 samples and was likely due to early spring conditions (ANOSIM [two-way] by month Global $R$ : 0.333; significance level of sample statistic: 0.001; among year Global $R$ ): 0.369; significance level of sample statistic: 0.001 ). 


\section{Zooplankton}

Rotifers comprised the majority of total abundances, ranging from 65 to $98 \%$ on any given sample date (annual mean $=87.6 \%$, Fig. $7 \mathrm{C}$ ) in Thompson Lake during 2013-2014; however, the relative biomass of rotifers ranged from 3 to $85 \%$ across dates such that mean annual biomass was evenly distributed among cladocerans (annual mean $=37.3 \%, \quad$ range $=$ $6-84 \%$ ), copepods (annual mean $=30.2 \%$, range $=$ $4-72 \%$ ), and rotifers (annual mean $=31.0 \%$, Fig. 7D). Five species comprised $61 \%$ of mean annual biomass of rotifers, that included Polyarthra vulgaris (Carlin, 1943), P. dolichoptera (Idelson, 1925), Synchaeta spp., B. calyciflorus, and B. angularis (Gosse, 1851). Relative abundances of copepods ranged from 2 to $24 \%$ across sample dates (annual mean $=8.3 \%$, Fig. 7C), dominated by E. pectinifer, cyclopoid copepodites, and nauplii. Cladocerans comprised $<1$ to $12 \%$ of total abundances across dates (annual mean $=3.9 \%$, Fig. 7C) dominated by Bosmina

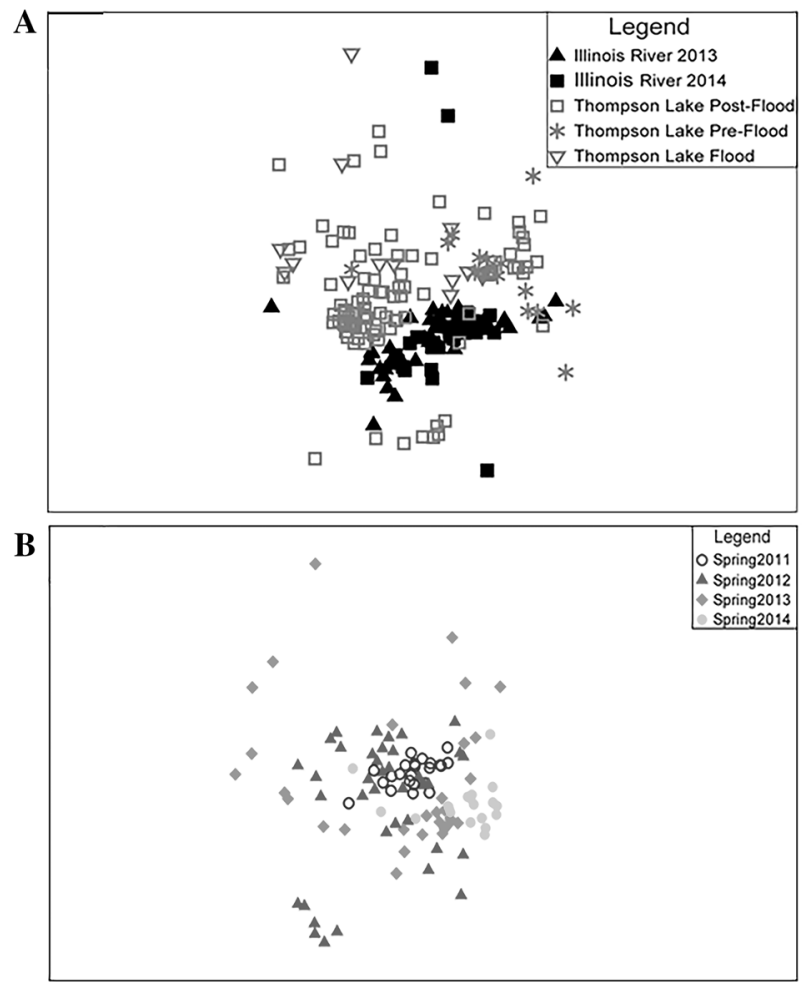

Fig. 7 Microfauna at Thompson Lake (Emiquon Preserve) includes MDS plots of bacterioplankton composition (ARISA) from the Illinois River $(2013,2014)$ and from Thompson Lake (pre-flood, flood, post-flood) (A), spring bacterioplankton longirostris (O.F. Müller, 1785), Ceriodaphnia spp., Daphnia spp., including D. lumholtzi, and C. sphaericus. Ostracods comprised $<1 \%$ of annual abundances and $1.3 \%$ of total annual biomass. Mean annual microcrustacean biomass for Thompson Lake was $56.4 \pm$ $12.6 \mu \mathrm{g}$ dry mass $(\mathrm{DM}) \mathrm{l}^{-1}$ and species diversity $\left(\mathrm{H}^{\prime}\right)$ was 1.23. Cladoceran and copepod densities remained low throughout the sampling year (Fig. 8A) relative to rotifer densities (Fig. 8B). Copepod densities showed four distinct peaks during the sampling year (Fig. 8A) in late-spring early summer (June), autumn (OctoberNovember), mid-winter (February) under the ice, and again in late-spring (May). Cladoceran densities remained low throughout much of the sampling year apart from an early autumn peak (September), a secondary peak in November, and a late-spring peak in May (Fig. 8A). Rotifer densities peaked during the latesummer (August) when copepod and cladoceran densities were lowest, during the winter underneath ice cover (December), and after ice melt in late February into early spring (Fig. 8B). As in Long Lake, total zooplankton
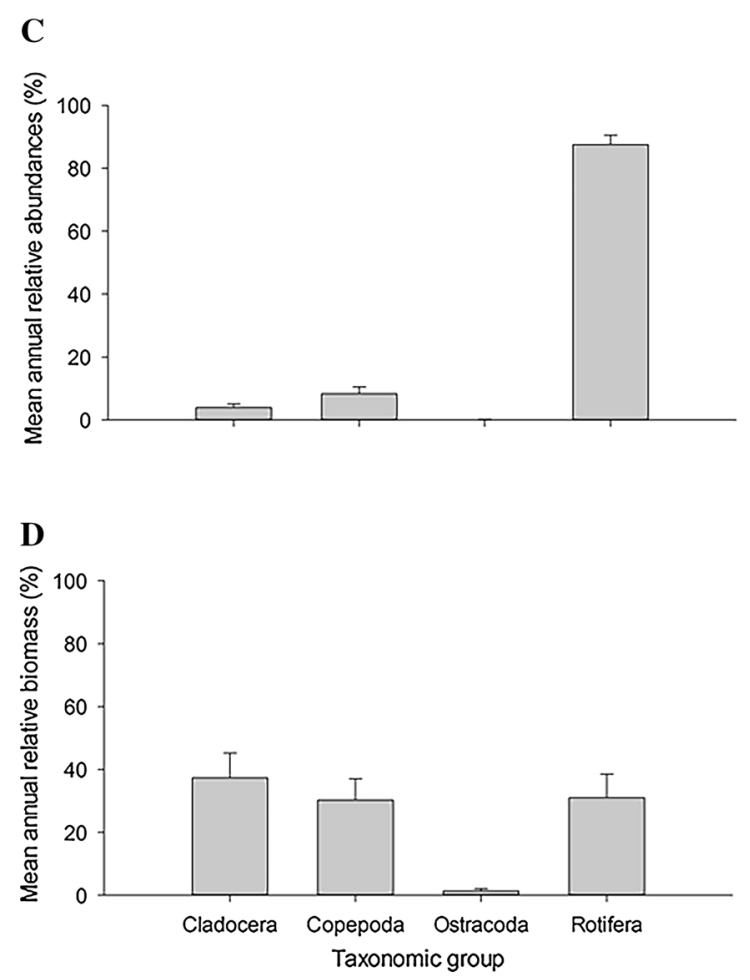

ARISA data coded by year for Thompson Lake (B), and relative abundances (C) and biomass (D) of major microcrustacean taxonomic groups 
Fig. 8 Mean ( \pm 1 SE) abundances of copepods and cladocerans $(\mathbf{A})$, rotifers (B), and total microcrustacean abundances and mean biomass $(\mathbf{C})$ collected monthly $(n=6)$ from Thompson Lake (Emiquon Preserve) late-May 2013 through April 2014
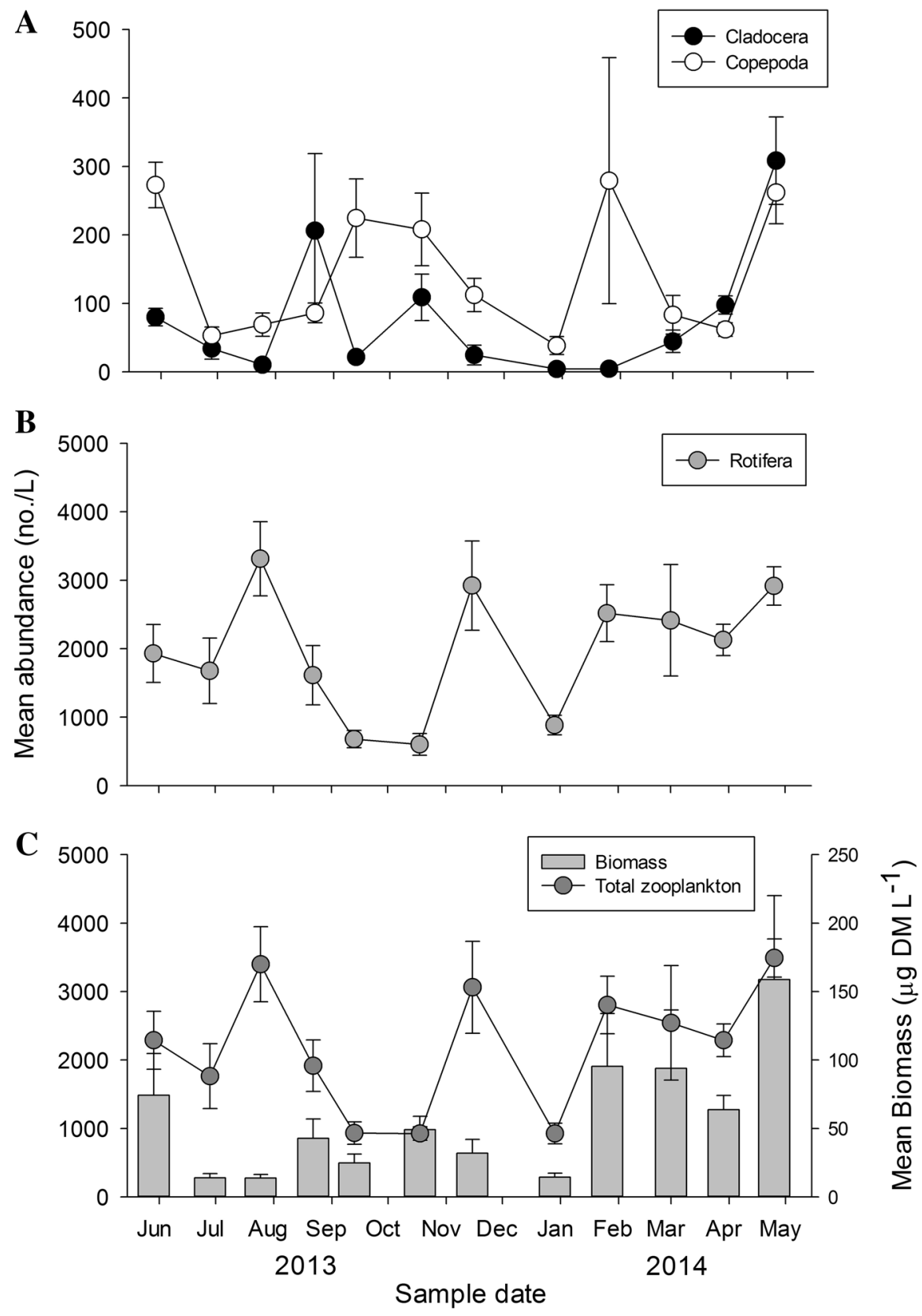

abundance patterns (Fig. 8C) were highly influenced by rotifer densities. Biomass patterns reflected three annual peaks in early summer, late autumn through early winter, and from ice melt through spring (Fig. 8C).

\section{Aquatic vegetation}

Total area of wetland vegetation and associated cover types in Emiquon Preserve was $14.9 \%$ greater in autumn 2013 than the long-term average. Specifically, aquatic bed (i.e., submersed and floating-leaf aquatic vegetation; $+13.6 \%)$ and persistent emergent $(+98.2 \%)$ plant communities were greater in autumn 2013 than the long-term average, whereas, the nonpersistent emergent plant community $(-30.2 \%)$ and open water $(-10.3 \%)$ were less than the long-term average (Fig. 9A). American pondweed (Potamogeton nodosus Poir) was the dominant aquatic plant 
species after the flood, compared to 2012 when Eurasian water milfoil (Myriophyllum spicatum L.), southern naiad (Najas guadalupensis [Spreng.] Magnus), and coontail (Ceratophyllum demersum L.) codominated with American pondweed, and secondarily with Sago pondweed (Stuckenia pectinata [L.] Börner) as a sub-dominant occurrence.

\section{Fishes}

Fish species richness in Thompson Lake consistently increased each year since restoration began in 2007, and declined by only one species after the 2013 flood (Fig. 9B). Major species included gizzard shad (D. cepedianum), black crappie (Pomoxis nigromaculatus Lesueur, 1829), largemouth bass (M. salmoides), and bluegill (L. macrochirus; VanMiddlesworth et al., 2016). In terms of productivity and abundance, the size structure of bluegill in 2013 showed the same broad range of sizes (i.e., ages) and a very large 2013 young-of-the-year cohort $<50 \mathrm{~mm}$, similar to patterns observed at Merwin Preserve (Fig. 9C).

\section{Waterbirds}

Use days for dabbling ducks $(+13.8 \%)$, diving ducks $(+8.4 \%)$, and total waterbirds $(+29.9 \%)$ were greater in autumn 2013 than the long-term average at Emiquon Preserve (Table 2). Use days for granivores $(-3.3 \%)$ and piscivores $(-26.2 \%)$ were less, but herbivores $(+56.6 \%)$ and invertivores $(+14.6 \%)$ were greater in autumn 2013 than the long-term average. Total use days during spring 2014 were less for dabbling ducks $(-28.2 \%)$, diving ducks $(-16.1)$, and total waterbirds $(-5.7)$ compared to the long-term average. Piscivores $(-20.4 \%)$, granivores $(-42.1 \%)$, and invertivores $(-27.5 \%)$ use days were less, whereas, herbivore use days $(47.7 \%)$ were greater in spring 2014 than the long-term average.

\section{Simulating frequency of river-floodplain connectivity}

Based on simulations of Illinois River levels during 1980-2014 and the elevation of the current levee breach, water levels in the Illinois River would have been sufficient to likely inundate $>50 \%$ of Merwin Preserve ( $>130 \mathrm{~m}$ AMSL) in 27 of 35 years $(77 \%)$ and provide shallow-water habitat preferred by waterbirds during peak spring waterfowl migration in March (Fig. 10). During August and September of the same years, river levels would have inundated significant portions of the preserve in 13 of 35 years (37\%) such that the growth of herbaceous vegetation prior to autumn waterfowl migration would have been negatively affected. Conditions suitable for moist-soil habitat after late-summer drawdown would likely have occurred in only 15 of 35 years (43\%) for successive years. Based on simulations of Illinois River levels during 1980-2014 and the elevation of the proposed water control structure $(131.7 \mathrm{~m})$, water levels could be manipulated for annual drawdown and subsequent re-flooding in $91.4 \%$ of years examined at the Emiquon Preserve using pumps and a water control structure under a managed connection scenario (Fig. 10).

\section{Discussion}

Floodplain lakes and wetlands have been greatly altered or degraded in the Midwest since the early twentieth century. However, increased recognition of the importance of these habitats to large river systems has resulted in revitalized efforts focused on restoration and long-term management of their ecological structure and function. There is much information supporting hydrology as the driver of floodplain structure and function that includes inundation frequency and duration; however, we have little understanding of the resiliency of restored floodplain wetlands to flood pulses, especially in highly altered river systems. The opportunity to explore this unique situation in restoration ecology presented itself during a major flood on the Illinois River flood in 2013.

The 2013 flood on the Illinois River was the largest in magnitude since 1922, and immediately altered the trajectory of restoration at the Merwin Preserve that transformed the site from a restored, isolated wetland complex to a partially connected floodplain with highly variable water levels for an extended period of the year. Potential tradeoffs of river connectivity within this restored lake-wetland complex became apparent based on the responses of the biotic communities and abiotic processes to this new hydrologic regime. In contrast, the same flood had a negligible impact on biotic communities and abiotic processes at the Emiquon Preserve due to the limited changes in 

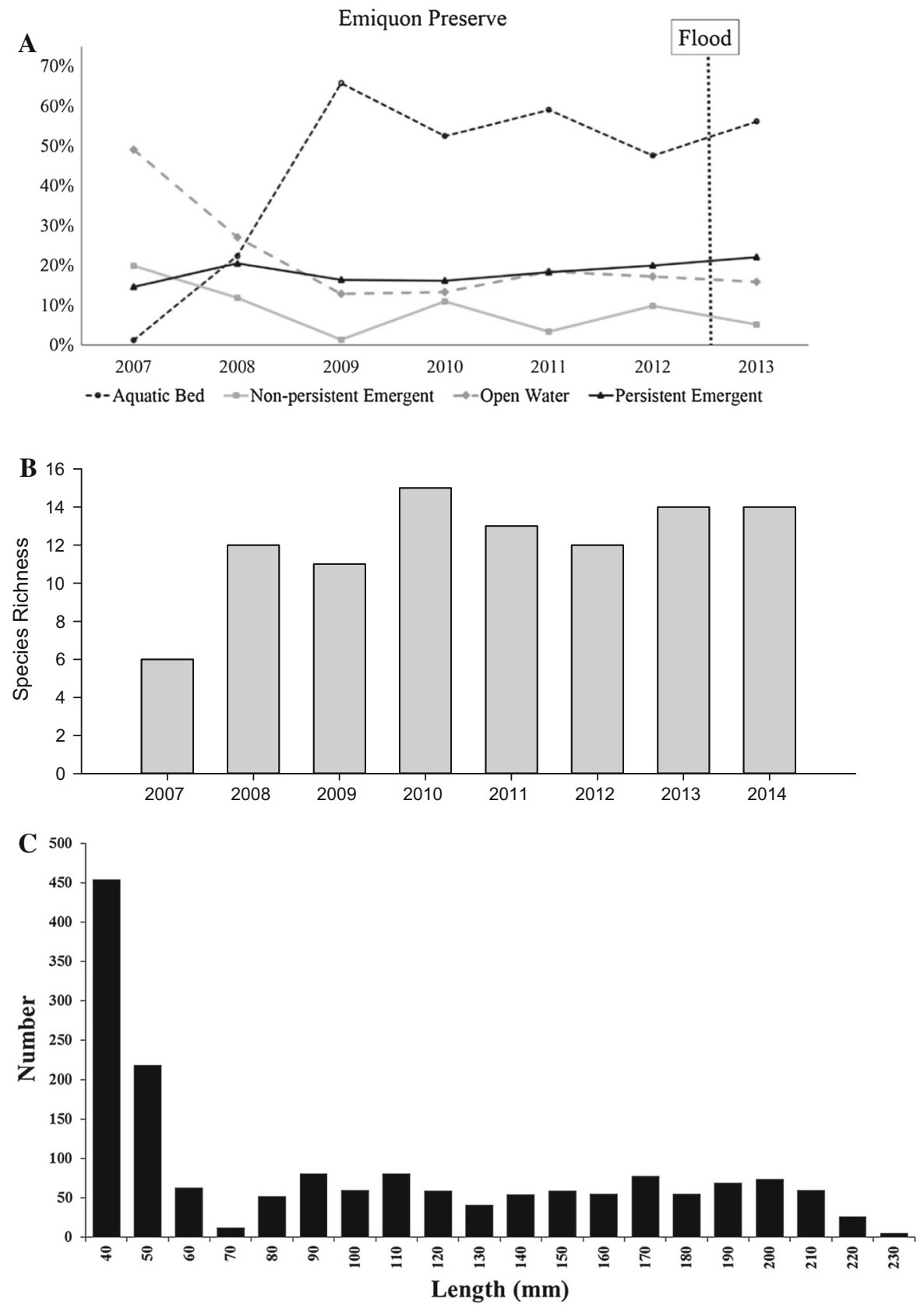

Fig. 9 Percent cover of aquatic vegetation types at Thompson Lake (Emiquon Preserve) during autumn 2012 and 2013 (A), total fish species richness 2007-2014 (B) and bluegill (Lepomis

hydroperiod and other hydrologic characteristics. These case studies illustrate how differences in duration and magnitude of river connections can affect biotic and abiotic communities of restored floodplain wetlands and lakes. Documenting these tradeoffs provides some insights for management macrochirus) population size structure (C) collected at the preserve July through October 2013

decisions related to reconnecting isolated floodplains with highly altered large rivers.

Partial connection to the Illinois River at the Merwin Preserve increased nutrient inputs to the backwater site that stimulated extremely high algal production throughout the summer and early autumn. 


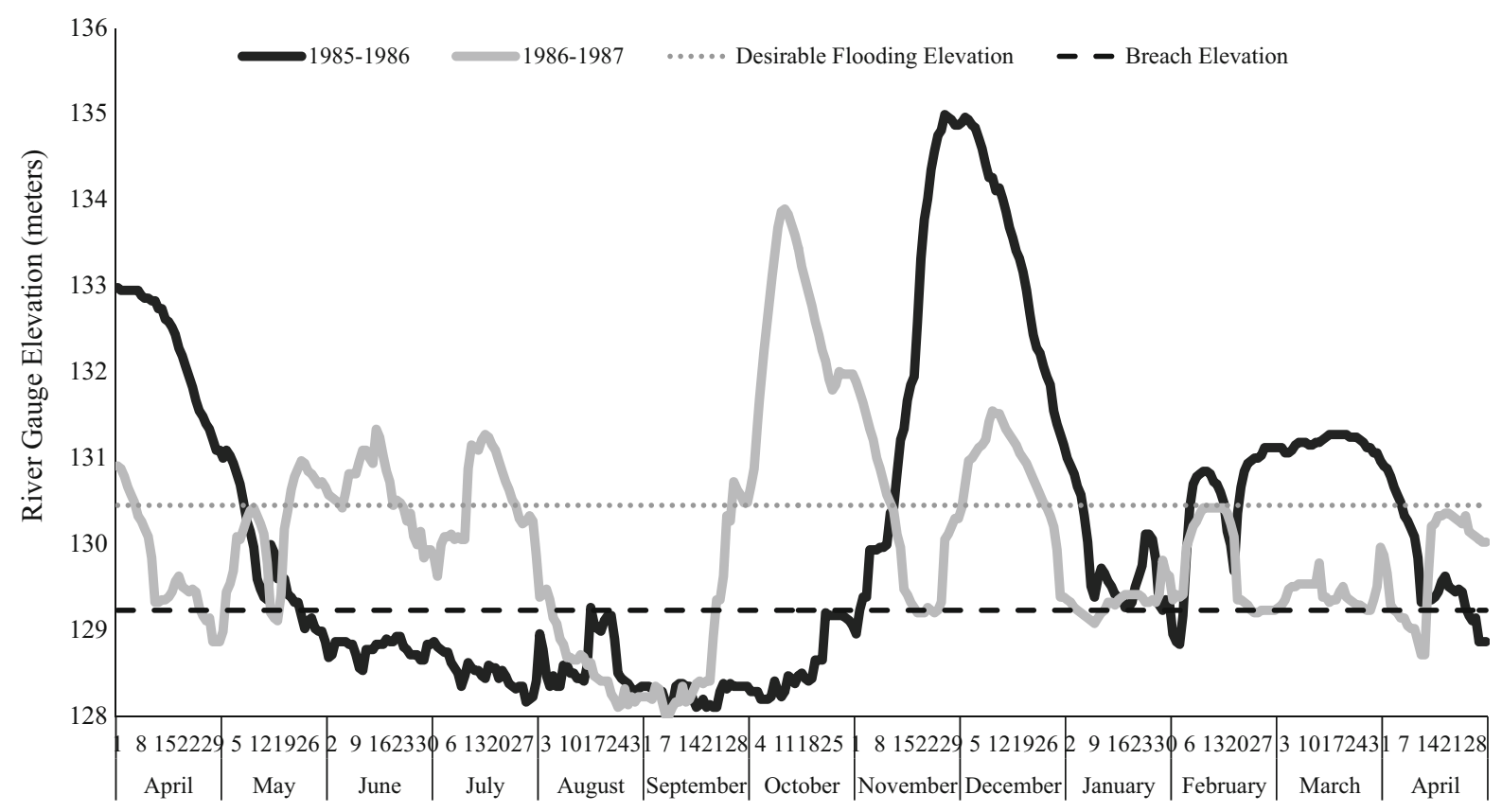

Fig. 10 Surface water elevations at the Illinois River La Grange Lock and Dam (3.5 km upstream of the Merwin Preserve) relative to the levee breach elevation at the Merwin Preserve $(129.2 \mathrm{~m})$. Also shown is the desirable river elevation when $>50 \%$ of the preserve would be inundated providing maximum use for waterbirds $(130.5 \mathrm{~m})$. Possible inundation

Nutrient pulses and productivity resulted in higher trophic level responses including a clear bacterioplankton species and abundance shift and higher zooplankton densities. Increased zooplankton densities immediately after the flooding were likely linked to the introduction of riverine species and augmented reproduction of existing backwater zooplankton (Górski et al., 2013). Zooplankton assemblage structure was heavily influenced by riverine inputs, dominated by rotifers in terms of both density and total biomass as reported from other studies within the Illinois River (Schuyler et al., 2009; Sass et al., 2014). Increased copepod densities after spring and winter inundation events support the riverine nature of the zooplankton community at the Merwin Preserve. While many factors could influence overall biomass and taxonomic distribution of zooplankton at this site, the size structure of bluegill suggests high predation pressure on larger cladoceran and copepod species. In addition, prolonged and variable inundation during spring and summer of 2013 eliminated emergent and aquatic bed vegetation that would have provided some refuge for larger zooplankton species. Reduced scenarios are shown that would have supported moist-soil vegetation and habitat for spring and autumn migrating waterbirds (1985-1986) and that would have been unfavorable for waterfowl (1986-1987), had the breach existed during these years

vegetation also corresponded to a substantial decline in waterbird densities compared to previous years; however, subsequent spring flooding did create an extensive shallow-water habitat for migrating waterbirds in 2014.

In contrast to the total inundation that occurred at the Merwin Preserve, the 2013 flood raised water levels at the Emiquon Preserve by only $0.3 \mathrm{~m}$ over 6 days. This addition of river flood waters did trigger an initial response in the bacterial community; however, water quality measurements and the bacteria composition quickly returned to those typically found in summer. These responses reinforce observations of quick-response and resilience of bacteria to the surrounding environmental conditions, and assumptions that short-term changes in pelagic bacteria species and abundances were likely due to river water inoculation rather than subsequent incubation in the lake under new and altered conditions. Equal distributions of total zooplankton biomass among the three major taxonomic groups indicate that the influence of river inundation was minimal compared to the Merwin Preserve. Although bluegill data suggest the potential 
for these fish to exert strong predation pressure at Emiquon, the presence of large areas of aquatic bed likely provided high-quality refuge areas for larger zooplankton species. Similar pulses of young-of-year bluegill in the two preserves suggest that the differences in flood scenarios were not significant enough to interfere with the fish reproduction patterns, although much lower recruitment did occur at the Merwin Preserve. Minor changes in the waterbird and vegetation communities at the Emiquon Preserve suggest that these were more related to changes in water levels rather than to a trophic cascade effect. Results indicate that restored lake and wetland habitats at the Emiquon Preserve were resilient to small inputs of flood water, and thus, a managed connection allowing entry of limited floodwaters should not compromise a floodplain restoration project unless other factors (e.g., introduced species) are associated with water movement (Lemke et al., 2014).

Partial river reconnection at the Merwin Preserve created high water levels during spring and early summer, followed by a progression from stagnant, warm waters to dry conditions during the post-flood summer that greatly altered vegetation conditions. Late-summer drawdowns exposed mudflats important for migrating shorebirds (Smith et al., 2012) and produced moist-soil vegetation for migrating waterfowl (Stafford et al., 2011) that also resulted in the loss of nearly all submersed and floating-leaf aquatic vegetation. Similar elimination of aquatic vegetation from fluctuating water levels during the growing season has occurred among backwater lakes and wetlands with partial connectivity to the Illinois River (Bellrose et al., 1983; Moore et al., 2010; Stafford et al., 2010). In contrast, minor flooding at Emiquon in 2013 likely provided increased area for aquatic vegetation to proliferate (Hine et al., 2016).

Growth of the moist-soil and other herbaceous vegetation at the Merwin Preserve during the summer produced excellent forage conditions for waterfowl, and yet, the late-summer drawdown limited available surface water for the autumn migrating birds. In contrast, large numbers of spring-migrating waterbirds used Merwin Preserve in 2014 as high river levels inundated the abundant moist-soil vegetation produced the preceding summer. Spring and summer floods created spawning and rearing habitat for riverine fishes within Merwin and piscivorous bird use days increased during autumn 2013, likely in response to the entrapment of riverine fishes as Illinois River waters receded. Bird use was less than previous years for most other guilds, especially granivores and herbivores.

Lakes and wetlands with partial river connections are somewhat "boom or bust" for waterfowl and fish habitat quality. "Boom" conditions occur when river water levels recede during the late-summer that allow for drawdowns in the connected lakes and wetlands during autumn and winter with subsequent increased river levels that shallowly inundate floodplain areas the following spring (Bellrose et al., 1979). These conditions create high-quality spring foraging habitat for waterbirds and vegetated, shallow-water spawning and nursery habitat for fish; however, it can result in limited and less dependable autumn waterbird habitat compared to similar isolated wetlands (i.e., "bust"). In contrast, fish reproduction capacity can be highly diminished (i.e., "bust") when the flood pulse occurs sometime other than spring or when high spring water depths reduce establishment of high-quality vegetation associated with spawning and rearing success. Although a partial river connection may benefit some fish and waterbird taxa (e.g., Bellrose et al., 1979; Sparks et al., 1998), current conditions at the Merwin Preserve would likely have resulted in quality habitat for both autumn and spring-migrating waterfowl in $<50 \%$ of the last 35 years. Without a way to manage the depth or timing of inundation at sites with partial connectivity to the river, these lakes and wetlands will often fail to produce quality habitat for autumn- or spring-migrating waterfowl and provide only limited spawning and nursery habitat for fishes.

Greater river connectivity in other systems has been correlated with increased diversity of fish assemblages (Dembkowski \& Miranda, 2011). Prior to 2013, these two isolated preserves were highquality habitats that were protected by levees from potential degradation related to unpredictable and highly altered river conditions. Moreover, fish communities inside the Emiquon and Merwin Preserves were generally more diverse and had a different sizeage structure than those found in the Illinois River (Solomon et al., 2014; VanMiddlesworth et al., 2016). The levee breach at the Merwin Preserve allowed large numbers of riverine fish to enter the site that substantially increased species richness; however, species composition did not change appreciably with the exception of the introduction of bighead and 
silver carp species. (Solomon et al., 2014; VanMiddlesworth et al., 2014).

Synopsis

Responses to flood pulse events are balanced by four factors that together define the boundaries of ecosystem impact: flood duration, flood frequency, water level magnitude, and the time of year that flood disturbance occurs (Amoros \& Bornette, 2002). Intensive spring rains created the initial flood pulse in our study, and yet, it was the nature of the connection (i.e., notch depth in a levee) that defined the duration and condition of post-flood conditions. Partial reconnection enabled high water levels during the summer that eliminated the growth of submersed aquatic, floating-leaf, and persistent emergent aquatic vegetation that benefit herbivorous waterfowl, summer-nesting waterbirds, and most riverine fish species. High water temperatures and shallow waters during summer drawdown contributed to high algal production and increased organic matter decomposition creating unfavorable dissolved oxygen conditions for fishes, but the drawdown also produced mudflats that provided feeding habitats for migrating shorebirds. Striking a balance between favorable and unfavorable conditions is the essence of managing these restored river-floodplain systems.

Our study emphasizes the importance of water level management to biotic structure and function, in particular as the critical nature of the timing and duration of inundation. As predicted, flooding at Emiquon was a mild perturbation and the site exhibited minimal changes in plant and animal diversity, water quality, or habitat characteristics. However, flood waters did inundate potential moist-soil and mudflat habitats, reducing foraging areas for migrating waterbirds and creating a beneficial increased denitrification potential. Denitrification potential has been shown to increase with higher nitrate loadings and labile organic carbon (Gayle et al., 1989; Richardson et al., 2004), and these conditions were met with the entry of relatively high-nutrient Illinois River waters and likely a pulse of dissolved carbon from flooding of nearby fields. Our overall prediction that a more intensive and sustained flood at Merwin would have a greater impact than at Emiquon was also documented. Nutrient loadings from the river to the Merwin Preserve supported an initial algal bloom that increased oxygen levels shortly after the flood. The subsequent collapse in algal production, in tandem with increased summer temperatures and reduced water depths, resulted in nearly anaerobic conditions in the lake basin. These conditions could be expected to re-occur with subsequent spring floods at this and similarly connected backwaters in the future. In contrast, short-term, low volume floods may have positive effects on wetlands by pulsing nutrients and introducing intermediate disturbances to the system.

Documentation of the effects of reconnecting floodplain wetlands and lakes to adjacent river systems is needed as restoration activities and management of floodplain rivers increase and are especially important for highly modified river systems. These two case studies provide quantification of the benefits and potential tradeoffs of reconnecting restored floodplain areas to highly altered river systems, as well as insights into the resiliency of floodplain restorations to catastrophic floods in heavily altered river systems. Managed connections can clearly be beneficial to continuity of floodplain diversity and will undeniably require comprehension of the balance between local flood pulse dynamics and the needs of native and migratory species.

Current conditions at the Merwin and Emiquon Preserves represent a hybrid state between historical river-floodplain relationships and novel restoration design (Higgs et al., 2014). Recreation of sustainable river-floodplain ecosystems at these sites will undoubtedly require the incorporation of hydrological controls that manage flood pulses to navigate and appropriately integrate altered river conditions. While these controlled connections may represent a transitional management role of restoring individual historical floodplain lakes and wetlands, the larger question remains of how to move from restoration of several land tracts (i.e., regional scale) to whole systems (i.e., landscape scale).

Acknowledgements We thank K. D. Blodgett, J. Walk, J. Beverlin, T. Hobson, and others at The Nature Conservancy for access to the Emiquon and Merwin Preserves and providing data in-kind; M. Cruce of Cruce Aviation for flight services and A. Yetter and M. Horath for collecting aerial inventory data; C. S. Hine, M. M. Horath, A. P. Yetter, G. Fretueg, and J. M. Osborn for assistance with vegetation data collection and analyses; Illinois Department of Natural Resources and the Wildlife and Sport Fish Restoration program through the U.S. Fish and Wildlife Service for support for aerial surveys and fisheries data in-kind; M. Scott for molecular technical 
assistance (University of Illinois [UI] Urbana-Champaign); B. Grebliunas for measurement of denitrification potential (Illinois State University); and D. Kellerhals for field and laboratory technical work (UI Springfield). Zooplankton identification and biomass estimations were completed by BSA Environmental Services, Inc., OH. This work was funded through the National Science Foundation DEB-RAPID grant $\# 1347077$ to $\mathrm{M}$. J. Lemke, A.F. Casper, K. Dungey, and H. Hagy, The University of Illinois Springfield's Therkildsen Field Station at Emiquon, and by the Illinois Natural History Survey of the Prairie Research Institute at the UI Urbana-Champaign.

Open Access This article is distributed under the terms of the Creative Commons Attribution 4.0 International License (http:// creativecommons.org/licenses/by/4.0/), which permits unrestricted use, distribution, and reproduction in any medium, provided you give appropriate credit to the original author(s) and the source, provide a link to the Creative Commons license, and indicate if changes were made.

\section{References}

Amoros, C. \& G. Bornette, 2002. Connectivity and biocomplexity in waterbodies of riverine floodplains. Freshwater Biology 47: 761-776.

APHA (American Public Health Association), 1998. Standard Methods for the Examination of Water and Waste Water, 21st ed. American Public Health Association, Washington, D.C.

Bajer, P. G., G. Sullivan \& P. W. Sorensen, 2009. Effects of a rapidly increasing population of common carp on vegetative cover and waterfowl in a recently restored Midwestern shallow lake. Hydrobiologia 632: 235-245.

Bayley, P. B., 1995. Understanding large river:floodplain ecosystems. BioScience 45: 153-158.

Beaver, J. R., C. E. Tausz, T. R. Renicker, G. C. Holdren, D. M. Holser, E. E. Manis, K. C. Scotese, C. E. Teacher, B. T. Vitanye \& R. M. Davidson, 2014. The late summer crustacean zooplankton in western U.S.A. reservoirs reflects ecoregion, temperature and latitude. Freshwater Biology. doi:10.1111/fwb.12338.

Bellrose, F. C., F. L. Paveglio Jr. \& D. W. Steffeck, 1979. Waterfowl populations and the changing environment of the Illinois River valley. Illinois Natural History Survey Bulletin 32: 1.

Bellrose, F. C., S. P. Havera, F. L. Paveglio, Jr., \& D. W. Steffeck, 1983. The fate of lakes in the Illinois River Valley. Illinois Natural History Survey Biological Notes 119.

Blodgett, K. D., T. Hobson, \& J. R. Herkert, 2007. The Nature Conservancy's floodplain restoration project at Spunky Bottoms. In Heske, E. J., J. R. Herkert, K. D. Blodgett, A. M. Lemke (eds), Spunky Bottoms: Restoration of a bigriver floodplain. Proceedings of the Spunky Bottoms Restoration Symposium, May 2003. Illinois Natural History Survey Special Publication 29: 2-3.

Boucek, R. E. \& J. S. Rehage, 2015. A tale of two fishes: using recreational angler records to examine the link between fish catches and floodplain connections in a subtropical coastal river. Estuaries and Coasts 38: S124-S135.

Burdis, R. M. \& R. J. H. Hoxmeier, 2011. Seasonal zooplankton dynamics in main channel and backwater habitats of the Upper Mississippi River. Hydrobiologia 667: 69-87.

Criss, R. E. \& E. L. Shock, 2001. Flood enhancement through flood control. Geology 29: 875-878.

Dembkowski, D. J. \& L. E. Miranda, 2011. Comparison of fish assemblages in two disjoined segments of an oxbow lake in relation to connectivity. Transactions of the American Fisheries Society 140: 1060-1069.

DeVries, D. R. \& R. A. Stein, 1991. Comparison of three zooplankton samplers: a taxon-specific assessment. Journal of Plankton Research 13: 53-59.

Edmundson, W. T., 1959. Freshwater Biology, 2nd ed. WileyInterscience, New York.

Galat, D. L., L. H. Fredrickson, D. D. Humburg, K. J. Bataille, J. R. Bodie, J. R. Jones, M. F. Knowlton, J. Kubisiak, A. C. McColpin, R. B. Renken \& R. D. Semlitsch, 1998. Flooding to restore connectivity of regulated, large-river wetlands. Bioscience 48: 721-733.

Galir, A. \& G. Palijan, 2012. Change in metazooplankton abundance in response to flood dynamics and trophic relations in Danubian floodplain lake (Kopački rit, Croatia). Polish Journal of Ecology 60: 777-787.

Garvey, J. E., J. H. Chick, M. W. Eichholz, G. Conover \& R. C. Brooks, 2007. Swan Lake Habitat Rehabilitation and Enhancement Project: Post-project Monitoring of Water Quality, Sedimentation, Vegetation, Invertebrates, Fish Communities, Fish Movement, and Waterbirds. Final report prepared for the St. Louis District, U.S. Army Corps of Engineers. St. Louis, MO

Gayle, B. P., G. D. Boardman, J. H. Sherrard \& R. E. Benoit, 1989. Biological denitrification of water. Journal of Environmental Engineering (United States) 115: 930-943.

Górski, K., K. J. Collier, I. C. Duggan, C. M. Taylor \& D. P. Hamilton, 2013. Connectivity and complexity of floodplain habitats govern zooplankton dynamics in a large temperate river system. Freshwater Biology 58: 1458-1470.

Hagy, H. M., C. S. Hine, M. M. Horath, A. P. Yetter, R. V. Smith \& J. D. Stafford, 2016. Waterbird response indicates floodplain wetland restoration. Hydrobiologia. doi:10. 1007/s10750-016-3004-3.

Haney, J. F. \& D. J. Hall, 1973. Sugar-coated Daphnia: a preservation technique for Cladocera. Limnology and Oceanography 18: 331-333.

Havera, S. P., 1999. Waterfowl of Illinois: Status and Management. Illinois Natural History Survey Special Publication 21.

Havera, S. P., K. E. Roat, \& L. L. Anderson, 2003. The Thompson Lake-Emiquon Story: The Biology, Drainage, and Restoration of an Illinois River Bottomland Lake. Illinois Natural History Survey Special Publication 25.

Heske, E. J. \& J. R. Herkert, 2007. Adaptive restoration. In Heske, E. J., J. R. Herkert, K. D. Blodgett, A. M. Lemke (eds), Spunky bottoms: restoration of a big-river floodplain. Proceedings of the Spunky Bottoms Restoration Symposium, May 2003. Illinois Natural History Survey Special Publication 29: 43-44. 
Higgs, E., D. A. Falk, A. Guerrini, M. Hall, J. Harris, R. J. Hobbs, S. T. Jackson, J. M. Rhemtulla \& W. Throop, 2014. The changing role of history in restoration ecology. Frontiers in Ecology and the Environment 12: 499-506.

Hine, C. S., H. M. Hagy, M. M. Horath, A. P. Yetter, R. V. Smith \& J. D. Stafford, 2016. Response of aquatic vegetation communities and other wetland cover types to floodplain restoration at Emiquon Preserve. Hydrobiologia. doi:10. 1007/s10750-016-2893-5.

Jackson, C. R. \& C. M. Pringle, 2010. Ecological benefits of reduced hydrologic connectivity in intensively developed landscapes. Bioscience 60: 37-46.

Junk, W. J., P. B. Bayley \& R. E. Sparks, 1989. The flood pulse concept in river-floodplain systems. Canadian Special Publication of Fisheries and Aquatic Sciences 106: 110-127.

Junk, W. J. \& K. M. Wantzen, 2004. The flood pulse concept: new aspects, approaches and applications - an update. In Welcomme, R. L. \& T. Petr (eds), Proceedings of the Second International Symposium on the Management of Large Rivers for Fisheries. Food and Agriculture Organization and Mekong River Commission, FAO Regional Office for Asia and the Pacific, Bangkok: 117-149.

Kreiling, R. M., J. P. Schubauer-Berigan, W. N. Richardson, L. A. Bartsch, P. E. Hughes, J. C. Cavanaugh \& E. A. Strauss, 2013. Wetland management reduces sediment and nutrient loading to the upper Mississippi River. Journal of Environmental Quality 42: 573-583.

Lemke, A. M. \& A. C. Benke, 2009. Spatial and temporal patterns of microcrustacean assemblage structure and secondary production in a wetland ecosystem. Freshwater Biology 54: 1406-1426.

Lemke, M. J., A. Casper, T. D. VanMiddlesworth, H. M. Hagy, J. Walk, D. Blodgett \& K. Dungey, 2014. Disturbance of flooding in two restored floodplains. Proceedings of the World Environmental and Water Resources Conference 2014: 1120-1127.

Lemke, M. J., H. M. Hagy, A. F. Casper \& H. Chen, 2017a. Floodplain wetland restoration in the Midwest. In Lenhart, C. \& P. C. Smiley Jr. (eds), Ecological Restoration in the Midwest: Building on the Legacy. University of Iowa Press, Iowa.

Lemke, M. J., S. F. Paver, K. Dungey, A. Kent, L. F. M. Velho, L. C. Rodrigues, D. Kellerhals \& M. Randle, 2017b. The recovery of microorganisms in a newly restored shallow lake on thee Illinois River floodplain. Hydrobiologia Special Issue: Large-scale Floodplain Restoration in the Illinois River Valley. Submitted.

Lewis, W. M. \& J. F. Saunders III, 1979. Two new integrating samplers for zooplankton, phytoplankton, and water chemistry. Archives Hydrobiologia 85: 244-249.

Lund, J. W. G., C. Kipling \& E. D. LeCren, 1958. The inverted microscope method of estimating algal numbers and the statistical basis of estimates by counting. Hydrobiologia 11: 143-170.

McCauley, E., 1984. The estimation of the abundance and biomass of zooplankton in samples. In Downing J. A., F. H. Rigler (eds) A Manual for the Assessment of Secondary Productivity in Fresh Waters. Blackwell Scientific Publishers, Hoboken: 228-265.
Moore, M., S. P. Romano \& T. Cook, 2010. Synthesis of upper Mississippi River system submersed and emergent aquatic vegetation: past, present, and future. Hydrobiologia 640: 103-114.

O’Hara, T. M., M. A. McClelland, K. S. Irons, T. R. Cook \& G. G. Sass, 2008. Effect of a recently completed habitat rehabilitation and enhancement project on fish abundances in La Grange Pool of the Illinois River using long term resource monitoring program data. U.S. Geological Survey, Upper Midwest Environmental Sciences Center, La Crosse, Wisconsin. LTRMP Technical Report 2008-T001.

Opperman, J. J., R. Luster, B. A. McKenney, M. Roberts \& A. W. Meadows, 2010. Ecologically functional floodplains: connectivity, flow regime, and scale. Journal of the American Water Resources Association 46: 211-226.

Pace, M. L. \& J. D. Orcutt, 1981. The relative importance of protozoans, rotifers and crustaceans in a freshwater zooplankton community. Limnology and Oceanography 26: 822-830.

Palmer, M. A., E. S. Bernhardt, J. D. Allan, P. S. Lake, G. Alexander, S. Brooks, J. Carr, S. Clayton, C. N. Dahm, J. F. Shah, D. L. Galat, S. G. Loss, P. Goodwin, D. D. Hart, B. Hassett, R. Jenkinson, G. M. Kondole, R. Lave, J. L. Meyer, T. K. O’Donnell, L. Pagano \& E. Sudduth, 2005. Standards for ecologically successful river restoration. Journal of Applied Ecology 42: 208-217.

Parkos III, J. J., V. J. Santucci Jr. \& D. H. Wahl, 2003. Effects of adult common carp (Cyprinus carpio) on multiple trophic levels in shallow mesocosms. Canadian Journal of Fisheries and Aquatic Sciences 60: 182-192.

Paver, S. F., K. R. Hayek, K. A. Gano, J. R. Fagen, C. T. Brown, A. G. Davis-Richardson, D. B. Crabb, R. Rosario-Passapera, A. Giongo, E. W. Triplett \& A. D. Kent, 2013. Interactions between specific phytoplankton and bacteria affect lake bacterial community succession. Environmental Microbiology 15: 2489-2504.

Pegg, M., Herbert, \& A. M. Lemke, 2007. Fish community development during wetland restoration of an agriculturally impacted floodplain system, 1999-2003. In Heske, E. J., J. R. Herkert, K. D. Blodgett, A. M. Lemke (eds), Spunky Bottoms: Restoration of a big-river floodplain. Proceedings of the Spunky Bottoms Restoration Symposium, May 2003. Illinois Natural History Survey Special Publication 29: 23-24.

Pennak, R. W., 1989. Fresh-water Invertebrates of the United States: Protozoa to Mollusca, 3rd ed. Wiley, New York.

Pinter, N., R. R. van der Ploeg, P. Schweigert \& G. Hoefer, 2006. Flood magnification on the River Rhine. Hydrological Processes 20: 147-164.

Prepas, E., 1978. Sugar-frosted Daphnia: an improved fixation technique for Cladocera. Limnology and Oceanography 23: 557-559.

Richardson, W. B., E. A. Strauss, L. A. Bartsch, E. M. Monroe, J. C. Cavanaugh, L. Vingum \& D. M. Soballe, 2004. Denitrification in the Upper Mississippi River: rates, controls, and contribution to nitrate flux. Canadian Journal of Fisheries and Aquatic Sciences 61: 1102-1112.

Robertson, A. I., P. Bacon \& G. Heagney, 2001. The responses of floodplain primary production to flood frequency and timing. Journal of Applied Ecology 38: 126-136. 
Ruttner-Kolisko, A., 1974. Plankton rotifers, biology and taxonomy. Die Binnengewasser 26: 1-146.

Sass, G. G., C. Hinz, A. C. Erickson, N. N. McClelland, M. A. McClelland \& J. M. Epifanio, 2014. Invasive bighead and silver carp effects on zooplankton communities in the Illinois River, Illinois, USA. Journal of Great Lakes Research 40: 911-921.

Schiemer, F., T. Hein \& P. Peduzzi, 2006. Hydrological control of system characteristics of floodplain lakes. Ecohydrology and Hydrobiology 6: 7-18.

Schuyler, J. S., J. H. Chick \& M. A. Pegg, 2009. Diet overlap among two Asian carp and three native fishes in backwater lakes on the Illinois and Mississippi rivers. Biological Invasions 11: 483-496.

Simons, J. H. E. J., C. Bakker, M. H. I. Schropp, L. H. Jans, F. R. Kok \& R. E. Grift, 2001. Man-made secondary channels along the river Rhine (the Netherlands); results of postproject monitoring. Regulated Rivers: Research and Management 17: 473-491.

Smith, R. V., J. D. Stafford, A. P. Yetter, M. M. Horath, C. S. Hine \& J. P. Hoover, 2012. Foraging ecology of fallmigrating shorebirds in the Illinois River valley. PLoS ONE 7(9): e45121.

Solomon, L. E., R. M. Pendleton, A. F Casper, N. T. Grider, \& R. B. Hilsabeck, 2014. Changes in the Fish Community at the Nature Conservancy's Merwin Preserve at Spunky Bottoms. Illinois Natural History Survey Technical Report 2014 (31)

Sparks, R. E., 1995. Need for ecosystem management of large rivers and their floodplains. BioScience 45: 168-182.

Sparks, R. E., J. C. Nelson \& Y. Yin, 1998. Naturalization of the flood regime in regulated rivers. BioScience 48: 706-720.

Sparks, R. E., K. D. Blodgett, A. F. Casper, H. M. Hagy, M. J. Lemke, L. F. M. Velho \& L. C. Rodrigues, 2016. Why experiment with success? Opportunities and risks in applying assessment and adaptive management to the Emiquon floodplain restoration project. Hydrobiologia. doi:10.1007/s10750-016-2785-8.

Stafford, J. D., M. M. Horath, A. P. Yetter, R. V. Smith \& C. S. Hine, 2010. Historical and contemporary characteristics and waterfowl use of Illinois River valley wetlands. Wetlands 30: 565-576.

Stafford, J. D., A. P. Yetter, C. S. Hine, R. V. Smith \& M. M. Horath, 2011. Seed abundance for waterfowl in wetlands managed by the Illinois Department of Natural Resources. Journal of Fish and Wildlife Management 2: 3-11.

Tiedje, J. M., 1982. Denitrification. In Page, A. L. (ed.), Methods of Soil Analysis. Part 2, 2nd ed. ASA and SSSA, Madison: 1011-1026.

Tockner, K. \& J. A. Stanford, 2002. Riverine flood plains: present state and future trends. Environmental Conservation 29: 308-330.

Tockner, K., F. Malard \& J. V. Ward, 2000. An extension of the flood pulse concept. Hydrological Processes 14: 2861-2883.

VanMiddlesworth, T. D., N. N. Michaels \& A. F. Casper, 2014. The Nature Conservancy's Emiquon Preserve: Fish and Aquatic Vegetation Monitoring 6-year (2007-2012) Report. Illinois Natural History Survey Technical Report 2014 (1)

Van Middlesworth, T. D., N. N. McClelland, G. G. Sass, A. F. Casper, T. W. Spier \& M. J. Lemke, 2016. Fish community succession and biomanipulation to control two common aquatic ecosystem stressors during a large-scale floodplain lake restoration. Hydrobiologia. doi:10.1007/ s10750-016-2696-8.

Ward, J. V., K. Tockner, U. Uehlinger \& F. Malard, 2001. Understanding natural patterns and processes in river corridors as the basis for effective river restoration. River Research and Applications 17: 311-323.

Wetzel, R. G. \& G. Likens, 2000. Limnological Analysis, 3rd ed. Springer, NY: 429.

Yin, Y., J. S. Winkelman \& H. A. Langrehr, 2000. Long Term Resource Monitoring Program Procedures: Aquatic Vegetation Monitoring. U.S. Geological Survey, Upper Midwest Environmental Sciences Center, La Crosse, Wisconsin. April 2000. LTRMP 95-P002-7. 8 pp. + Appendices A-C. 